Trakya Eğitim Dergisi

Cilt 10, Sayı 1

Ocak 2020, 92-111

Geliş Tarihi: 15.03.2019

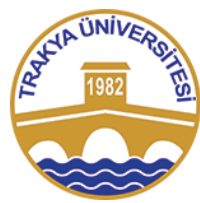

ISSN: 2630-6301
Trakya Journal of Education

Volume 10, Issue 1

January 2020, 92-111
Doi: $10.24315 /$ tred.540609

Araștırma Makalesi

Research Article

\title{
Kaynaştırma Sınıfına Devam Eden Zihin Yetersizliği Olan Öğrencilere Uygulanan Akran Zorbalığına İlişsin Öğretmen Görüşleri ${ }^{1}$
}

\section{Teachers' Opinions on Being Exposed to Bullying of Students With Intellectual Disability in Inclusive Classes}

\section{Zekiye Hande YILMAZ ${ }^{2}$, Asude MALKOÇ³}

ÖZ: $\mathrm{Bu}$ araştırmada, kaynaştırma sınıfina devam eden zihin yetersizliği olan öğrencilere normal gelişim gösteren öğrenciler tarafindan uygulanan akran zorbalığına ilişkin öğretmen görüşlerini belirlemek amaçlanmıştır. Çalışmada nitel araştırma yöntemlerinden durum çalışması kullanılmıştır. Araştırmanın çalışma grubunu 2016-2017 eğitim-öğretim yılında, Edirne İl Milli Eğitim Müdürlüğü'ne bağlı 15 ilkokulda görev yapan, 32 sınıf öğretmeni oluşturmaktadır. Veriler, yarı yapılandırılmış görüşme tekniği ile toplanmıştır. Araştırma sonucunda, öğretmenlerin akran zorbalığına ilişkin algıları, gözlemleri ve çözümleri temaları oluşturulmuştur. Öğretmenler akran zorbalığının sebebi olarak en s1k ailevi özellikleri dile getirmişlerdir. Zihin yetersizliği olan öğrencilerin tüm zorbalık türlerine (fiziksel, sözel, sosyal) maruz kaldığını ve en sık gözlenen zorbalık türünün sözel zorbalık olduğunu ifade etmişler; zorbalığın sıklıkla sınıf arkadaşları tarafından uygulandığını belirtmişlerdir. Akran zorbalığına ilişkin çözüm olarak öğretmenler bilgilendirme, uyarma ve empati kurdurma çalışmalarını yaptıklarını dile getirmişlerdir. Elde edilen bulgular, zihin yetersizliği olan öğrencilere uygulanan akran zorbalığını önlemeye yönelik çalışmalar yürütülmesi gerekliliğini ortaya koymaktadır.

Anahtar sözcükler: Kaynaştırma, zihin yetersizliği, akran zorbalığ

\begin{abstract}
In this study, it is aimed to determine the teachers' opinions about peer bullying experienced by the children with intellectual disability at inclusive classes from typically developing students. Of the qualitative research methodologies, case study design was used in this study. The study group consists of 32 classroom teachers working at 15 state primary schools in Edirne. The data was collected by semi-structured interview technique. As a result of this research, themes on the teachers' perceptions, their observations and their solutions for bullying were created. Most of the teachers expressed family characteristics as the reason for peer bullying. They stated that students with intellectual disability were exposed to all types of bullying (physical, verbal, social) and added that the most commonly observed type of bullying was verbal bullying. They reported that bullying was frequently practiced by classmates. As a solution to peer bullying, teachers stated that they were working on informing, warning and empathizing studies. The findings also suggest that studies should be conducted to prevent peer bullying applied to students with intellectual disability.
\end{abstract}

Keywords: Inclusion, intellectual disability, peer bullying

Cite this article as:

Y1lmaz, Z. H.. \& Malkoç, A. (2020). Teachers' Opinions on Being Exposed to Bullying of Students With Intellectual Disability in Inclusive Classes. Trakya Eğitim Dergisi, 10(1), 92-111.

\section{EXTENDED ABSTRACT}

\section{Introduction}

Intellectual disability is a form of inability characterized by remarkable limitations in both cognitive functions and adaptive behaviors (including conceptual, social, and practical abilities), which develops before the age of 18 (AAIDD, 2010). Individuals with intellectual disability have different qualities depending on the extent of their disabilities and educational requirements (Batu, 2000). Those with mild intellectual disability have enough competency to receive education in the same setting with their typically developing peers and demonstrate adaptation, yet this may bring about certain problems. These children have difficulty in understanding the friendly behaviors of peers, distinguishing whether

\footnotetext{
${ }^{1}$ Bu çalışma Zekiye Hande ÜNAL'ın Trakya Üniversitesi Sosyal Bilimler Enstitüsü’nde, Dr. Öğr. Üyesi Asude MALKOÇ’ un danışmanlığında hazırlanan yüksek lisans tezinden üretilmiştir. Çalışmanın özeti 18-22 Nisan 2018 tarihlerinde Antalya'da düzenlenen 27. Uluslararası Eğitim Bilimleri Kongresi'nde sözlü bildiri olarak sunulmuştur.

2 Arş. Gör., Trakya Üniversitesi, e- posta: zhandeunal@ trakya.edu.tr ORCID: 0000-0002-4886-5746

${ }^{3}$ Dr. Öğr. Üyesi, İstanbul Medipol Üniversitesi, e-posta: amalkoc@medipol.edu.tr ORCID: 0000-0002-9073-2752
} 
these behaviors are hostile or not, and resolving social conflicts (Leffert, Siperstein, \& Millikan as cited in Rowe, 2007). Pivik, McComas, and Laflamme (2002), however, found that inclusive students with special needs are excluded by their typically developing peers and bullied physically and socially. Their likelihood of being bullied is twice as high as the typically developing peers (Carter \& Spencer, 2006).

Olweus (1995) defined peer bullying as negative actions performed by a student or a group of students towards a victim-peer repeatedly and over time, involving physical violence, verbal abuse, derogatory and disturbing facial and body gestures, and excluding. For a behavior to be called as peerbullying, there has to be power imbalance between the bully-victim and the bully (the inability of the bully victim to defend him/herself against bullying). Olweus (1991), in a study involving 130.000 students, found out that $11.6 \%$ of primary school students (2-6 graders) are susceptible to bullying. Another study conducted in the United States of America focusing on students with disabilities reported that students are exposed to bullying with the following extent: $24.5 \%$ at primary-school level; $34.1 \%$ at secondary-school level, and $26.6 \%$ at high-school level. The same study found out that the students with intellectual disability, in particular, encounter bullying by $29.1 \%$ at primary-school level, $41.3 \%$ at secondary-school level, and 30.7\% at high-school level (Blake, Lund, Zhou, Kwok, \& Benz, 2012).

Cognitive and social skills of individuals with intellectual disability lag behind those of peers, which makes them more susceptible to mockery and exclusion. Thus, the basic intention of inclusive education, i.e. enabling the individuals with special needs to receive education in the same setting with their peers and achieving their inclusion into the society, is impaired. The present study intends to obtain data related to bullying faced by individuals with intellectual disability, and it is hoped that the findings will be useful in the development and implementation of intervention programs designed to prevent bullying towards these individuals. What is more, an analysis of the literature related to peer bullying in Turkey demonstrated that the existing research (Çınkır \& Kepenekçi, 2003; Kapçı, 2004; Kartal \& Bilgin, 2007; Kartal, 2008) have focused on typically developing children. No study has dealt with bullying towards individuals with intellectual disability and drawn on teachers' opinions on this phenomenon on a large-scale study. To this end, the present study aims to find out teachers' views on bullying of individuals with intellectual disability at inclusive schools. Thus, the study seeks answers to the following research questions:

1. How do teachers perceive bullying towards students with intellectual disability at inclusive schools?

2. What are teachers' observations of bullying towards students with intellectual disability at inclusive schools?

3. What solutions to bullying are proposed by teachers who have inclusive students?

\section{Method}

Of the qualitative research methodologies, case study design was used in this study. The study group is comprised of 32 (11 male, 21 female) class teachers working in 15 primary schools in Edirne. The data was collected by means of semi-structured interviews in the 2016-2017 academic semester. The interview form was developed by the researchers themselves. The researchers asked the interview questions to the participants, and the responses were tape-recorded and noted on the interview forms.

Descriptive analysis was employed in the data analysis. Prior to data analysis, during the stage of identifying themes for descriptive analysis, a pool of themes and sub-themes was formed based on the related literature and research questions. The themes and sub-themes were uploaded to Nvivo 11 Qualitative Data Analysis Program. Upon the completion of data collection, all transcriptions of interview recordings and the accompanying notes on the interview forms were also transferred to software and uploaded to Nvivo 11. The codes that emerged as a result of detailed data analysis were placed under the pre-determined themes and sub-themes.

Expert opinion was sought for to assure the reliability of data analysis conducted by the researcher; the expert was made to check if the data was coded according to the determined codes. The inter-rater reliability was found to be $86.6 \%$.

\section{Results and Discussion}

The themes about peer bullying were identified as follows in the study: "teachers' perceptions", "teachers' observations", and "teachers' solutions". The terms that teachers most frequently associated 
with peer bullying were "violence" and "pushing". For teachers, the major cause of bullying is familial factors. The teacher responses revealed that the most common types of bullying were, from the most to the least frequent, as follows: verbal bullying, social bullying, and physical bullying. As regards verbal abuse, the bullying behaviors teachers observe the most are mocking, verbal mobbing, and nicknaming. As to social bullying, the inclusive students are generally not invited to join games and excluded. Finally, in terms of physical bullying, the teachers reported that the students with special needs at inclusive schools are most often subject to hitting and pushing. It was also indicated that the bullies are generally the classmates. The peer bullying behaviors are most observed in the schoolyard, followed by classrooms, and toilets. The participants also stated that, when the inclusive students encounter bullying, the typically developing peers tend to protect and defend them. The teachers observe that the students with intellectual disability are adversely affected by bullying. Among the solutions to bullying expressed by the teachers are informing, warning, and empathy training. Only one participant said nothing was done to prevent bullying.

The related literature seems to be in concordance with the findings of the present study in terms of teachers' definition of peer bullying, perceptions of its possible causes, observation of the bullying types, common settings, and times for bullying, and solutions for the prevention of bullying. The participant teachers stated that students with intellectual disability are bullied by their peers verbally, socially, and physically and that they carry out several activities to find solutions for this problem. When these activities, as reported by teachers, and the occurrence frequency of bullying are taken into consideration, the solutions applied by teachers prove to be ineffective. The majority of teachers attributed bullying to factors related to families. However, among the solutions employed by teachers to prevent bullying, communicating with parents was rarely mentioned. One reason that may explain the insufficient acts towards preventing peer bullying is that most teachers think students with intellectual disability are not affected by bullying. Therefore, it is recommended that classroom teachers be informed of bullying through pre-service and in-service trainings and schools adopt large-scale approaches based on supervision and prevention. The findings of the study have shown that special activities should be organized aiming at families, classroom teachers, typically developing students, and students with special needs for the prevention of bullying towards students with intellectual disability.

\section{GİRIŞ}

Zihin yetersizliği, zihinsel işlevler ve kavramsal, sosyal ve pratik becerileri içeren uyumsal davranışların her ikisinde önemli sınırlılıklarla karakterize edilen bir yetersizlik türüdür ve bu yetersizlik 18 yaşından önce ortaya çıkmaktadır (AAIDD, 2010). Zihin yetersizliği olan bireyler yetersizliklerinin derecesine göre farklı özelliklere sahiptir. Bireysel farklılıklar çocukların eğitim gereksinimlerine de yansımaktadır. Hafif düzeyde zihin yetersizliği olan bireyler, normal gelişim gösteren akranlarıyla aynı ortamda eğitim alabilecek ve uyum sağlayabilecek yeterliliğe sahiptir. Kaynaştırma, özel gereksinimli öğrencinin gerekli destek hizmetler sağlanarak, tam ya da yarım zamanlı olarak kendisi için en az kısıtlayıcı eğitim ortamı olan genel eğitim sınıflarında eğitim görmesidir (Batu, 2000).

Hafif düzeyde zihin yetersizliği olan çocukların genel eğitim sınıflarına yerleştirilmesi beraberinde bazı sorunları da getirebilmektedir. $\mathrm{Bu}$ çocuklar; başka bir çocuğun iyi niyetli davranışlarını yorumlamada, onun davranışlarının düşmanca olup olmadığını anlamada ve sosyal bir çatışma durumunda bunu nasıl çözeceğini bulmada zorluk yaşarlar (Leffert, Siperstein, ve Millikan, 1999'dan akt. Rowe, 2007).

Öte yandan Pivik, McComas ve Laflamme'nin (2002) yaptıkları çalışmada, kaynaştırma ortamında eğitim alan özel gereksinimli öğrencilerin normal gelişim gösteren arkadaşları tarafindan dışlandıkları, fiziksel ve sosyal zorbalığa maruz kaldıkları belirtilmektedirler. Turhan (2007)'ın yaptığı çalışmada normal gelişim gösteren öğrencilerin çoğu özel gereksinimli öğrenci ile aynı sınıfta eğitim almak istemediğini, onların ayrı okullarda eğitim görmelerinin kendileri ve onlar için daha yararlı olacağını ifade etmişlerdir. Normal gelişim gösteren akranları ile karşılaştırıldığında, kaynaştırma ortamına yerleştirilen özel gereksinimli bireylerin zorbalığa maruz kalma oranı iki kat fazladır (Carter ve Spencer, 2006). 
Olweus (1995) akran zorbalığını, "bir öğrenci veya öğrenci grubu tarafından sürekli ve tekrarlı olarak gerçekleşen fiziksel şiddet, sözlü hakaret, yüz ve vücut hareketiyle karşısındakini rahatsız etme veya bir gruptan dışlama gibi olumsuz davranışlar" olarak tanımlamıştır. Akran zorbalığının gerçekleşmesi için, zorbalığı uygulayan ve zorbalığa maruz kalan öğrenci arasında güç dengesizliğinin olmas1 (zorbalığa uğrayan öğrencinin kendini olumsuz davranışlara karş1 savunamaması) gerekmektedir. Olweus (1993)' a göre akran zorbalığının sözel (direkt), fiziksel (direkt) ve sosyal/ilişkisel (dolaylı) olmak üzere üç türü vardır. Tehdit etme, isim takma, alay etme, sataşma gibi zarar verici davranışlar sözel zorbalık; vurma, itme, tekme atma veya kısıtlama, sıkıştırma gibi davranışlar fiziksel zorbalık ve kötü jest ve mimikler, kasıtlı bir şekilde bir gruptan dışlama veya kişinin istediği şeyleri reddetme gibi davranışlar sosyal/ilişkisel zorbalık olarak nitelendirilmektedir.

Olweus (1991), 130.000 öğrenci ile yürüttüğü çalışmada ilkokul düzeyindeki (2.-6. sınıf) çocukların \%11.6'sının zorbalığa maruz kaldığını belirtmiştir. Aynı çalışmada kızların \%12.5 'inin, erkeklerin ise \%11.6'sının zorbalığa uğradığı sonucuna ulaşılmıştır. Yetersizliği olan çocuklarla ilgili Amerika Birleşik Devletleri'nde yapılan bir çalışmada; yetersizliği olan çocukların ilkokul düzeyinde $\% 24.5$; ortaokul düzeyinde \%34.1 ve lise düzeyinde \%26.6'sının akran zorbalığına maruz kaldığ belirtilmektedir. Aynı çalışmada zihin yetersizliği olan çocukların; ilkokul düzeyinde \%29.1'inin, ortaokul düzeyinde \%41.3'ünün ve lise düzeyinde \%30.7'sinin zorbalığa maruz kaldığ1 sonucuna ulaşılmıştır (Blake, Lund, Zhou, Kwok, ve Benz, 2012).

Zihin yetersizliği olan bireylerin bilişsel ve sosyal becerileri akranlarından geridedir; bu durum zihin yetersizliği olan bireyleri, akranları tarafından alay edilmeye ve dışlanmaya açık duruma getirebilmektedir. Dolayısıyla kaynaştırma eğitiminin temel felsefesi olan özel gereksinimli bireylerin akranları ile aynı ortamda eğitim alarak toplumla bütünleşmeleri engellenmektedir. Yapılan çalışma ile zihin yetersizliği olan bireylere uygulanan akran zorbalığına ilişkin verilere ulaşılması hedeflenmiştir ve bu verilerin ileride özel gereksinimli bireylere uygulanan akran zorbalığını önlemeye ilişkin müdahale programları geliştirilmesi ve uygulanmasına katkı sağlayacağı düşünülmektedir. Yanı sıra, ülkemizde akran zorbalığ 1 ile ilgili yapılan çalışmalar incelendiğinde, mevcut çalışmaların (Çınkır ve Kepenekçi, 2003; Kapçı, 2004; Kartal ve Bilgin, 2007; Kartal, 2008) normal gelişim gösteren çocuklar üzerinde yapıldığı sonucuna ulaşılmış, zihin yetersizliği olan bireylere uygulanan akran zorbalığını belirlemeye yönelik öğretmen görüşlerine dayalı kapsamlı bir çalışmaya ulaşılamamıştır. Bu nedenle bu araştırmanın amacı, kaynaştırma sınıfına devam eden zihin yetersizliği olan öğrencilere normal gelişim gösteren öğrenciler tarafından uygulanan akran zorbalığına ilişkin öğretmen görüşlerini belirlemektir. Bu amaç doğrultusunda aşağıdaki sorulara yanıt aranmıştır:

1. Kaynaştırma sınıfına devam eden zihin yetersizliği olan öğrencilere akranları tarafindan uygulanan zorbalığa ilişkin öğretmenlerin algıları nelerdir?

2. Kaynaştırma sınıfına devam eden zihin yetersizliği olan öğrencilere akranları tarafindan uygulanan zorbalığa ilişkin öğretmenlerin gözlemleri nelerdir?

3. Kaynaştırma öğrencisi bulunan öğretmenlerin akran zorbalığına ilişkin çözümleri nelerdir?

\subsection{Araştırmanın Deseni}

\section{YÖNTEM}

Durum çalışmasında bir veya birkaç durum derinlemesine araştırılır. Bir duruma ilişkin faktörler (bireyler, olaylar, ortamlar, süreçler) bütüncül bir yaklaşımla araştırılır ve bu faktörlerin durumu nasıl etkilediğine ve bu durumdan nasıl etkilendiklerine odaklanılır (Yıldırım ve Şimşek, 2013). Durum çalışmasının bu özelliklerinden hareketle, kaynaştırma sınıfına devam eden zihin yetersizliği olan öğrencilere uygulanan akran zorbalığına ilişkin öğretmen görüşlerinin belirlenmesinde bütüncül bir yaklaşımla, durum ve duruma ilişkin faktörlerle ilgili derinlemesine araştırma yapılmasına olanak vermesi sebebiyle bu araştırmada nitel araştırma yöntemlerinden durum çalışması kullanılmıştır.

\section{2. Çalışma Grubu}

Araştırmanın çalışma grubunun belirlenmesi sürecinde Edirne İl Milli Eğitim Müdürlüğü'ne bağlı Edirne Rehberlik ve Araştırma Merkezi'nden ilkokul düzeyinde olup, zihin yetersizliği tanısına sahip ve kaynaştırma kararı bulunan öğrencilerin bulunduğu ilkokulların isimleri alınmış ve Edirne İl Milli Eğitim Müdürlüğü’nden alınan izin doğrultusunda 2016-2017 eğitim-öğretim y1lı içinde, Edirne 
İl Milli Eğitim Müdürlüğü’ne bağl1 15 ilkokulda görev yapan 35 öğretmene ulaşılmıştır. Ancak iki öğretmenin zihin yetersizliğine sahip kaynaştırma öğrencilerinin devamsız olduğu tespit edildiği ve bir diğer öğretmen ise gönüllü katılımı kabul etmediği için çalışma grubuna dâhil edilmemiştir. Dolayısıyla çalışma grubu 11'i erkek 21'i kadın, toplam 32 sınıf öğretmeninden oluşmaktadır. Öğretmenlerin 19'unun mesleki deneyimi 20 yıl ve üzeri, yedisinin 15-20 yıl, beşinin 11-15 yıl ve birinin 1-5 yı1 arasındadır. Sınıf öğretmenlerinden üçü 1.sınıfta, yedisi 2. sinıfta, altısı 3. sinıfta ve 16's1 4. sinıfta görev yapmaktadır. Kaynaştırma uygulaması yapılan sınıf mevcutlarına bakıldığında öğretmenlerin 28'i sınıf mevcudunun 20-30 arasında, dördü 30-40 arasında olduğunu ifade etmiştir. Sınıf öğretmenlerinden 21'i sınıfinda bir kaynaştırma öğrencisi bulunduğunu, beşi sınıfında iki kaynaştırma öğrencisi bulunduğunu, üçü sınıfında üç kaynaştırma bulunduğunu ve üçü de sınıfinda dört kaynaştırma öğrencisi bulunduğunu belirtmiştir.

\subsection{Veri Toplama Araçları}

Kaynaştırma sınıfina devam eden zihin yetersizliği olan öğrencilere normal gelişim gösteren öğrenciler tarafindan uygulanan akran zorbalığına ilişkin öğretmen görüşlerini belirlemek amaciyla yapılan çalışmanın verilerini toplamak için yarı yapılandırılmış görüşme formu geliştirilmiştir. Yarı yapılandırılmış görüşme formu alanyazın doğrultusunda hazırlanmış ve iki uzmanın görüşlerine başvurulmuştur. Uzman görüşleri doğrultusunda tekrar düzenlenerek forma son şekli verilmiştir. Yarı yapılandırılmış görüşme formunda akran zorbalığı teriminin çağrışımı, zihin yetersizliği olan öğrenciye uygulanan akran zorbalığı türleri ve bu davranışların süresi ve sıklığı, gerçekleştiği ortam ve zaman, kasıtlı zarar verme davranışları, akran zorbalığının kim (sınıf arkadaşları veya okuldaki diğer öğrenciler) tarafından uygulandığı, zihin yetersizliği olan öğrencinin akran zorbalığından nasıl etkilendiği ve öğretmeni ile bu durumu paylaşıp paylaşmadığı, akran zorbalığı uygulanırken diğer öğrencilerin tutumları ve davranışları, akran zorbalığının sebepleri ve öğretmenin akran zorbalığını önlemek için aldığı tedbirler hakkında toplam 16 açık uçlu soru bulunmaktadır.

\subsection{Verilerin Toplanması ve Analizi}

Yarı yapılandırılmış görüşmeler detaylı bilgi edinmek amacıyla, açık uçlu sorulardan oluşan ve esnek bir yapıda yürütülen görüşmelerdir (Britten, 1995). Araştırma sürecinde sağladığı esneklik ve bu sayede durum ile ilgili daha detaylı veri toplanmasına izin vermesi sebebiyle bu araştırmada veriler yarı yapılandırılmış görüşmeler ile toplanmıştır. Gönüllü katılımı kabul eden öğretmenlerle görüşmeler, öğretmenler tarafından belirlenen uygun zaman dilimlerinde, öğretmenlerin görev yaptıkları okullarda uygun bir odada veya boş bir sınıfta gerçekleştirilmiştir. Yarı yapılandırılmış görüşme formunda yer alan sorular araştırmacı tarafından öğretmenlere yöneltilmiş ve ses kaydı alınmasına izin veren dokuz öğretmenin yanıtları ses kayıt cihazı ile, ses kaydına izin vermeyen 23 öğretmenin yanıtları araştırmacı tarafından görüşme formuna not edilerek kaydedilmiştir.

Araştırma verilerinin analizinde nitel veri analiz yöntemlerinden betimsel analiz kullanılmıştır. Betimsel analiz için temaların oluşturulma aşamasında verilerin toplanmasından önce, alanyazından ve araştırma sorularından yola çıkılarak bir tema grubu oluşturulmuş ve verilerin yer alacağı temalar ile alt temalar belirlenmiştir. Temalar ve alt temalar Nvivo 11 Nitel Veri Analiz Programı'na yüklenmiştir.

Araştırma verileri toplandıktan sonra ses kayıtlarının transkripti bilgisayar üzerinde yapılmıştır. Ses kaydı alınamayan öğretmenlerle yapılan görüşmeler sırasında araştırmacının kaydettiği görüşme notları da bilgisayar ortamına aktarılmıştır. Bilgisayar ortamına aktarılan tüm görüşme dökümleri Nvivo 11 Nitel Veri Analiz Programı'na yüklenmiştir. Verilerin tek tek analiz edilmesi ile oluşturulan kodlar daha önce belirlenen temalar ve alt temalara yerleştirilmiştir.

Araştırmacı tarafından yapılan analizlerin güvenirliğini sağlamak için uzman görüşüne başvurulmuş, verilerin belirlenen temalara göre kodlanıp kodlanmadığını tespit etmek için analiz etmesi istenmiştir. Araştırmacı ve uzman arasında uyumun sağlanıp sağlanmadığı her bir soru için [güvenirlik yüzdesi görüş birliği / (görüş birliği + görüş ayrıllı̆̆) x 100] formülü ile hesaplanmıştır. Değerlendiriciler aras1 güvenirliğin \%86.6 olduğu belirlenmiştir. Elde edilen güvenirlik yüzdesi doğrultusunda araştırmacı tarafından analizler gerçekleştirilmiş, bu analizlere bulgular bölümünde yer verilmiştir.

Verilerin analizlerini desteklemek, görüşme yapılan kişinin fikirlerini çarpıcı bir şekilde yansıtmak ve yapılan betimlemeleri zenginleştirmek (Yıldırım ve Şimşek, 2013, s. 256) amacıyla 
öğretmenlerin ifadelerinden doğrudan alıntılar kullanılmış ve alıntılar yapılırken öğretmenlerin isimleri yerine Ö1, Ö2 şeklinde kodlar kullanılmıştır.

\section{BULGULAR}

Araştırmaya ilişkin temalar "öğretmenlerin akran zorbalığına ilişkin algıları”, "öğretmenlerin akran zorbalığına ilişkin gözlemleri” ve "öğretmenlerin akran zorbalığına ilişkin çözümleri” olarak belirlenmiştir.

\section{1. Öğretmenlerin Akran Zorbalığına İlişkin Algıları}

Öğretmenlerin akran zorbalığına ilişkin algıları temasına dair veriler, öğretmenlerin akran zorbalığı kavramına ilişkin çağrışımları ve öğretmenlerin akran zorbalığının sebeplerine ilişkin görüşleri alt temalarında açıklanmıştır.

\section{1. Öğretmenlerin Akran Zorbalığı Kavramına İlişkin Çağrışımları}

Öğretmenlerin akran zorbalığı ile ilgili algılarını belirlemek amacıyla, akran zorbalığı kavramına ilişkin çağrışımları ile ilgili görüşleri alınmış ve verdikleri yanıtların analizi sonucunda akran zorbalığı kavramına ilişkin çağrışımları ile ilgili bulgulara Tablo 1'de yer verilmiştir.

Tablo 1. Öğretmenlerin akran zorbalığı kavramına ilişkin çağrışımları

\begin{tabular}{lc}
\hline Akran zorbalı̆̆ kavramına ilişkin çağrışımlar & Frekans \\
\hline Şiddet uygulamak & 9 \\
İtmek & 8 \\
Vurmak & 6 \\
Küçümsemek & 6 \\
Baskı yapmak & 4 \\
Zorla bir şey yaptırmak & 4 \\
Alay etmek & 2 \\
\hline
\end{tabular}

Öğretmenlerle yapılan görüşmeler sonucunda, akran zorbalığ ile ilgili şiddet uygulamak $(n=9)$, itmek $(n=8)$, vurmak $(n=6)$, aşağılamak $(n=6)$, bask1 yapmak $(n=4)$, zorla bir şey yaptırmak $(n=4)$ ve alay etmek $(\mathrm{n}=2)$ ifadelerini dile getirdikleri görülmektedir. "Aynı yaştaki çocukların birbirine karşı uyguladiğ şiddet" (Ö14) ve "Fiziksel ve psikolojik şiddet uygulaması" (Ö24) ifadelerinde görüldüğü gibi öğretmenlerin akran zorbalığını en sık "şiddet" kavramı ile bağdaştırdıkları, bunun yanında "Öğrenciler arasında son yıllarda karşılaştığımız bir konu. Vurma itme gibi düşünüyorum." (Ö17) ifadesinde olduğu gibi fiziksel zorbalık çeşitlerinden "vurmak" ve "itmek" i özellikle vurguladıkları görülmektedir.

"Küçümseme, onu sınıf içinde yapma zor durumda bırakma" (Ö28) ifadesinde olduğu gibi öğretmenlerin altısı akran zorbalığını "küçümsemek" kavramı ile bağdaştırmışlardır.

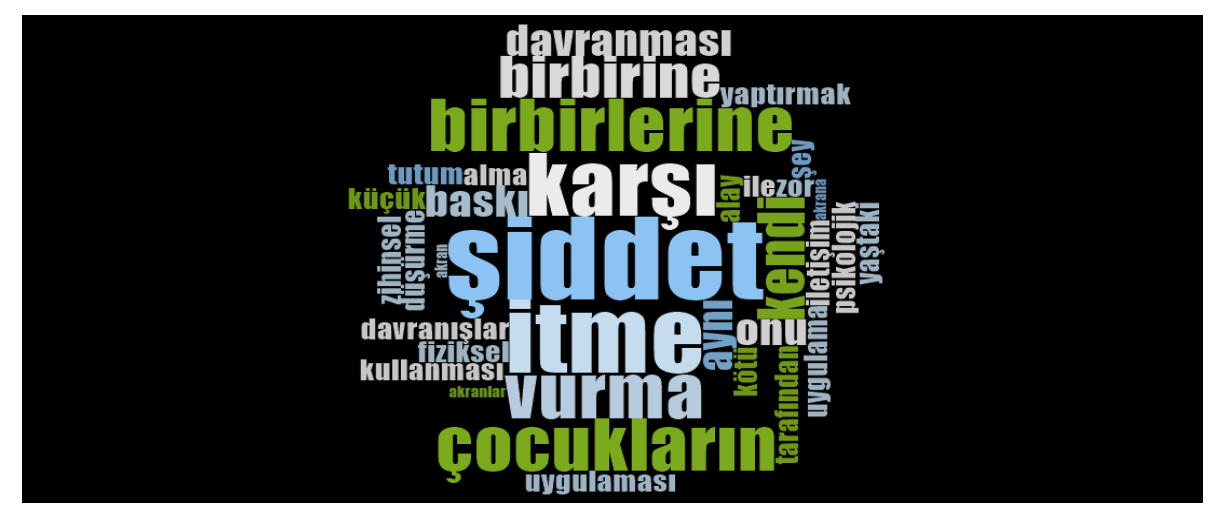

Görsel 1. Öğretmenlerin akran zorbalığı kavramına ilişkin çağrışımları

\section{2. Öğretmenlerin Akran Zorbalığının Sebeplerine İlişkin Görüşleri}

Öğretmenlerin akran zorbalığının sebepleri ile ilgili görüşlerini içeren bulgular Tablo 2' de sunulmuştur. 
Tablo 2. Öğretmenlerin akran zorbalığının sebeplerine ilişkin görüşleri

\begin{tabular}{lc}
\hline Akran zorbalığının sebepleri & Frekans \\
\hline Zorbalık uygulayan öğrencinin ailevi özellikleri & 15 \\
Zorbalık uygulayan öğrencinin kendini üstün ve güçlü görmesi & 9 \\
Kaynaştırma öğrencisinin gelişimsel geriliğinin olması & 4 \\
Zorbalı uygulayan çocukların kaynaştırma öğrencisinin farklı özelliklere & 3 \\
sahip olduğunu kavrayamaması & \\
\hline
\end{tabular}

Akran zorbalığının sebepleri ile ilgili veriler incelendiğinde, görüşme yapılan 32 öğretmenden 15 'i zorbalığın, zorbalık uygulayan öğrencinin ailevi özelliklerinden kaynaklandığını; dokuzu zorbalık uygulayan öğrencinin kendini üstün ve güçlü görmesinin zorbalığa sebep olduğunu; dördü kaynaştırma öğrencisinin gelişimsel geriliğinin olmasının zorbalığa maruz kalmasında bir etken olduğunu; üçü zorbalık uygulayan çocukların kaynaştırma öğrencisinin farklı özelliklere sahip olduğunu kavrayamamasından dolayı zorbalık uyguladığını belirtmişlerdir.

Ailenin yetersizliği olan bireylere karşı olumsuz bir tutuma sahip olmasının zorbalığa sebep olabileceği ile ilgili öğretmen görüşlerinden örnekler aşağıda verilmiştir.

“...evdeki anne babanın tavrı da önemli. Mesela evdeki anne baba bırak şu salağg, işste şu geri zekâlıyı, şu bilmem neyi, zaten o işte şöyle deyip te çocuklarına karşı böyle ifadeler kullanırsa çocukta artık ona o gözle bakıyor. Ama evdeki aile dinleyip hani en azından yorumsuz kalırsa bu konuda ha öyle mi şeklinde geçiştirirse ya da işte o da öyledir şeklinde olumlu telkinlerde bulunursa çocuk da olumlu buluyor." (Ö20)

“...velilerin çok etkisi var. İşte onunla oynama. O deli okuluna gidiyor işte arada bazı günler özel eğitime gitse bile deli okulu oluyor hemen.” (Ö30)

Aile içerisinde kendisine veya başka bir aile üyesine zorbalık uygulanan çocukların, akranlarına zorbalık uygulama eğilimleri olabileceğini dile getiren öğretmenlerin ifadelerinden bir örneğe aşağıda yer verilmiştir.

“En baş sebebi öğrencinin ailede gördüğ̈̈ sıkntılar. Ailede dövmeyi görüyorsa okulda da bunu yansittyor." (Ö26)

Öğretmenler, zorbalık uygulayan öğrencilerin aileleri tarafından bireysel farklılıklar hakkında bilgilendirilmemelerini akran zorbalığının bir diğer sebebi olarak görmektedir. Öğretmenlerin bu görüşü ile ilgili alıntı aşağıda sunulmuştur.

"Aileye bağllyorum. Aile bazı insanların fiziksel ve zihinsel sıkıntılar yașayacağını normal cocuklara anlatmamıs." (Ö2)

Görüşülen öğretmenlerden dokuzu ise akran zorbalığının sebebi olarak; zorbalık uygulayan öğrencinin kendisini, karşısındaki öğrenciden üstün ve güçlü gördügünü ve bundan dolayı zorbalık uyguladığını dile getirmişlerdir. Aşağıda öğretmenlerin ifadeleri ile ilgili örneğe yer verilmiştir.

"O çocuğa biraz zayıf olduğu için, farklı olduğu için, kendini savunamayacă̆ iç̧in yapıyorlar."

Görüşülen öğretmenlerden dördü kaynaştırma öğrencisinin gelişimsel geriliğinden dolayı bazı davranışlar sergilediğini ve bu davranışların sonucunda akranları tarafından zorbalığa maruz kaldığını dile getirmişlerdir. Aşağıda bu görüşü dile getiren öğretmenlerin ifadelerinden alıntılar sunulmuştur.

"Algı yetersizliği var kaynaştırma öğrencisinde bazı şeyleri algılayamıyor. Sinırlarını tam algllayamıyor. Konuştuklarının genel kabul görmediğini bilmiyor. El hareketi yapıyor çocuklara." (Ö5)

“Zihinsel-fiziksel gelișim geriliği olması.” (Ö6)

Normal gelişim gösteren öğrencilerin, yetersizliği olan çocuğun bireysel farklılıklarını algılayamamaları akran zorbalığının bir diğer nedeni olarak görülmektedir. Bu doğrultuda görüş bildiren iki öğretmenin ifadelerinden alıntılar aşağıda sunulmuştur.

“...savunmasız biriyle alay ediyorlar diye suçlamıyorum çocukları karşılarında farklı biri olduğunu ve ona anlayıș göstermeleri gerektiğini bilmiyorlar yaşayarak onu ögrenmiş oluyorlar sınıfin içinde işte." (Ö9)

“Çocukların farkında olmayışı...farklı olduğunun farkında olmamaları." (Ö7) 


\section{2. Öğretmenlerin Akran Zorbalığına İlişkin Gözlemleri}

Öğretmenlerin zihin yetersizliği olan öğrenciye uygulanan akran zorbalığg ile ilgili gözlemlerini belirlemek amacıyla; uygulanan akran zorbalığının türleri, uygulanan akran zorbalığının sıklığı ve süresi, gözlendiği ortamlar, gözlendiği zamanlar, akran zorbalığını uygulayan kişi, akran zorbalığı uygulanırken diğer çocukların tutum ve davranışları, zihin yetersizliği olan öğrencinin zorbalık hakkında öğretmeni ile paylaşımları, akran zorbalığının kasıtlı olup olmaması, öğrencinin kendisine uygulanan zorbalıktan olumsuz etkilenme durumu ile ilgili görüşleri alınmış ve verilen yanıtların analizi sonucunda elde edilen bulgular sunulmuştur.

\section{1. Öğrenciye Uygulanan Akran Zorbalığı Türlerine İlişkin Öğretmen Görüssleri}

Öğretmenlerle yapılan görüşmelerin analizi sonucunda, zihin yetersizliği olan öğrenciye uygulanan akran zorbalığı türlerine ilişkin bulgulara Tablo 3'de yer verilmiştir.

Tablo 3. Öğrenciye uygulanan akran zorbalığı türlerine ilişkin öğretmen görüşleri

\begin{tabular}{lc}
\hline Uygulanan akran zorbalığı türleri & Frekans \\
\hline Sözel zorbalık & 14 \\
Sosyal zorbalık & 11 \\
Fiziksel zorbalık & 10 \\
\hline
\end{tabular}

Zihin yetersizliği olan öğrenciye akranları tarafindan uygulanan zorbalık türlerine ilişkin, 14 öğretmen öğrenciye sözel zorbalık uygulandığını, 11 öğretmen sosyal zorbalık uygulandığını ve 10 öğretmen de fiziksel zorbalık uygulandığını ifade etmişlerdir.

\subsection{1. Öğrenciye Uygulanan Sözel Zorbalık Çeşitlerine İlişkin Öğretmen Görüşleri}

Zihin yetersizliği olan öğrenciye uygulanan sözel zorbalık çeşitlerine ilişkin öğretmen görüşlerini içeren bulgular Tablo 4' de sunulmuştur.

Tablo 4. Öğrenciye uygulanan sözel zorbalık çeşitlerine ilişkin öğretmen görüşleri

\begin{tabular}{lc}
\hline Uygulanan sözel zorbalıklar & Frekans \\
\hline Dalga geçme/ Alay etme & 9 \\
Sözel olarak sataşma & 5 \\
İsim takma & 5 \\
\hline
\end{tabular}

Zihin yetersizliği olan öğrenciye akranları tarafından sözel zorbalık uygulandığını ifade eden öğretmenlerin dokuzu öğrencilerinin sözel zorbalık çeşitlerinden "dalga geçme/ alay etme", beşi "sözel olarak sataşma", beşi de "isim takma" davranışlarına maruz kaldıklarını dile getirmişlerdir.

Normal gelişim gösteren öğrencilerin, yetersizliği olan öğrenciye sözel zorbalık çeşitlerinden dalga geçme/alay etme davranışlarını sergilediklerini dile getiren öğretmenlerin ifadelerinden alıntılar aşağıda sunulmuştur.

"Ders esnasinda, ders esnasinda oluyor genelde konu anlatırken mesela soru sorduğumda ben kalkacağım ben kalkacă̆ım o kalkamadı̆̆ı zaman onunla alay ediyorlar. "(Ö16)

"Dördüncü sınıflar onu sıkıştırıp alay etmeye dalga geçmeye çalıștılar. Onu bir dairenin içine alıp etrafinda bir şeyler yaptıklarını gördüm." (Ö29)

Yapılan görüşmelerde öğretmenler, normal gelişim gösteren öğrencilerin zihin yetersizliği olan öğrenciye; "geri zekâlı” (Ö25), “deli” (Ö21; Ö30), “özürlü” (Ö16) ve "aptal” (Ö9; Ö16) şeklinde isimler taktıklarını belirtmişlerdir.

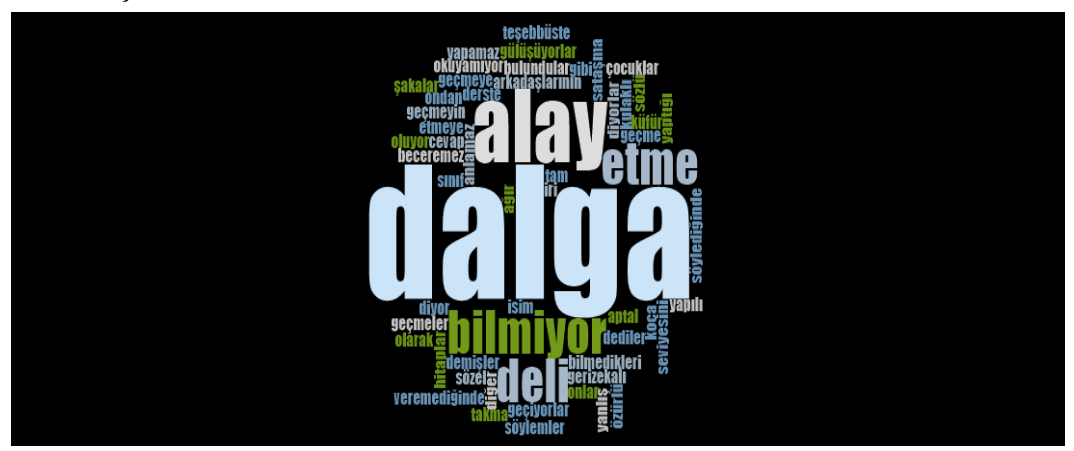

Görsel 2. Öğrenciye uygulanan sözel zorbalık çeşitlerine ilişkin öğretmen görüşleri 


\subsection{2. Öğrenciye Uygulanan Sosyal Zorbalık Çeşitlerine İlişkin Öğretmen Görüşleri}

Zihin yetersizliği olan öğrenciye uygulanan sosyal zorbalık çeşitlerine ilişkin öğretmen görüşlerini içeren bulgular Tablo 5' de yer almaktadır.

Tablo 5. Öğrenciye uygulanan sosyal zorbalık çeşitlerine ilişkin öğretmen görüşleri

\begin{tabular}{lc}
\hline Uygulanan sosyal zorbalıklar & Frekans \\
\hline Oyuna almama/ almak istememe & 7 \\
Dişlama & 2 \\
Küçük görme & 1 \\
Ifftira atma & 1 \\
\hline
\end{tabular}

Tablo 5' de görüldüğü gibi, öğretmenlerin zihin yetersizliği olan öğrenciye uygulanan sosyal zorbalık çeşitlerinden en sık "oyuna almama/ almak istememe" yi $(\mathrm{n}=7)$ dile getirdikleri görülmektedir. Aşağıda oyuna almama/ almak istememe ile ilgili öğretmen ifadelerinden örneklere yer verilmiştir.

"Oyun oynarken öğretmenim bizim grubumuzda olmasin diyorlar ama her zaman olmuyor. Çarpma- bölme ile oyunlar oynuyoruz derslerde, çocuklar grup oluyorlar almak istemiyorlar gruba." (Ö32)

"Çocukları serbest bıraktığımda kenarda gördüğümde soruyorum, beni oyuna almıyorlar diyor." ("̈3)

Öğretmenlerden ikisi zihin yetersizliği olan öğrencinin akranları tarafından dışlandığını dile getirmişlerdir. Öğretmenlerden birinin ifadesinden alıntı aşağıda sunulmuştur.

“Dışlama bir müddet oldu." (Ö29)

Öğretmenlerden biri zihin yetersizliği olan öğrencinin akranları tarafindan küçük görüldüğünü dile getirmiştir.

Görüşülen öğretmenlerden biri sınıfındaki özel gereksinimli öğrencinin akranları tarafindan suçlandığını ve öğrencilerin ona iftira attıklarını ifade etmiştir. Öğretmenin bu görüşü ile ilgili doğrudan alıntı aşağıda sunulmuştur.

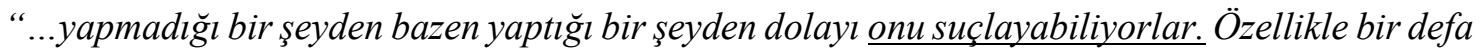
şey demişler, ögrretmenin silgilerinden bir tanesini Merve'nin çantasina atalım sonra da onda işte arayalım ya da ögretmenim işte bulduk deriz senaryo kuruyorlar ki öğretmen onun farkına varsın bak bu tuhaf bir çocuk davranışları kötü bize kötü davranıyor ama onun üzerine iftira da atmaya çalıșlyorlar. Bu şekilde suçlayalım çünkü ögretmen Merve'yi bir taraftan tutuyor gibi gözüküyor çünkü özel bir durumu var farkındalar, başka türlü öğretmeni inandıramayız Merve'nin kötü olduğuna diye bu şekilde de yaptıkları oluyor." (Ö30)

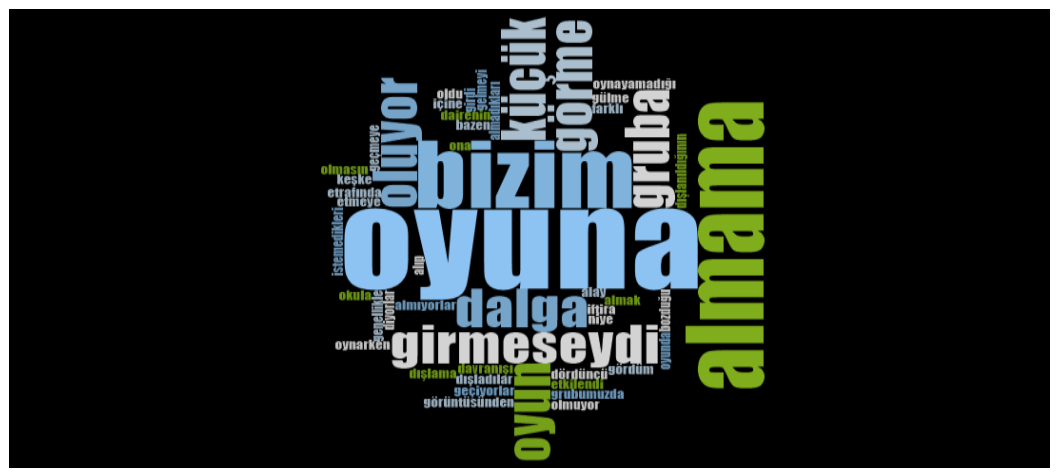

Görsel 3. Öğrenciye uygulanan sosyal zorbalık çeşitlerine ilişkin öğretmen görüşleri

\subsection{3. Öğrenciye Uygulanan Fiziksel Zorbalık Çeşitlerine İlişkin Öğretmen Görüş̧leri}

Zihin yetersizliği olan öğrenciye uygulanan fiziksel zorbalık çeşitlerini belirlemek amacıyla öğretmenlerin görüşleri alınmış ve verdikleri yanıtların analizi sonucunda fiziksel zorbalık çeşitlerine ilişskin bulgular Tablo 6' da sunulmuştur. 
Tablo 6. Öğrenciye uygulanan fiziksel zorbalık çeşitlerine ilişkin öğretmen görüşleri

\begin{tabular}{lc}
\hline Uygulanan fiziksel zorbalıklar & Frekans \\
\hline Vurma & 6 \\
İtme & 4 \\
Çelme takma & 2 \\
Tokat/yumruk atma & 1 \\
Merdivenden itme & 1 \\
Tekme atma & 1 \\
Ayağına basma & 1 \\
\hline
\end{tabular}

Öğretmenlerle yapılan görüşmeler sonucunda, öğretmenlerin zihin yetersizliği olan öğrenciye uygulanan fiziksel zorbalık ile ilgili "vurma" $(n=6)$ ve "itme" $(n=4)$ ifadelerini vurguladıkları görülmektedir. Öğretmenlerden ikisi çelme takma, biri yumruk/tokat atma, biri merdivenden itme, biri tokat atma, biri ayağına basma davranışlarının sergilendiğini belirtmiştir.

Zihin yetersizliği olan öğrenciye akranları tarafından "vurma" davranışının uygulandığını dile getiren öğretmen görüşlerinden alıntılar aşağıda yer almaktadır.

"Genellikle vuruyorlar. " (Ö30)

İtme davranışıyla görüş dile getiren öğretmenlerden alıntılar aşağıda sunulmuştur.

"Vurma, itme, merdivenden itme, çelme takma" (Ö6)

(Ö10), zihin yetersizliği olan öğrenciye dersi anlamamasından dolayı fiziksel zorbalık uygulandığı "Biraz onu itip kaktılar ilk dönemde 1. sinıfta. Anlamıyor diye” şeklinde ifade etmiştir.

Öğretmenlerin diğer fiziksel zorbalık türlerine ilişkin görüşlerinden alıntılar aşağıda sunulmuştur.

"CCelme takuld, şakalaşıyormuş gibi yaparak vuruldu tokat atma, yumruk atma şaka hepsine bu kilıf uyduruldu." (Ö9)

"Mesela şimdi geldi ayă̆ıma bastı dedi. Çocuğa tekme atıyorlar. Ayağına basıyorlar." (Ö25)

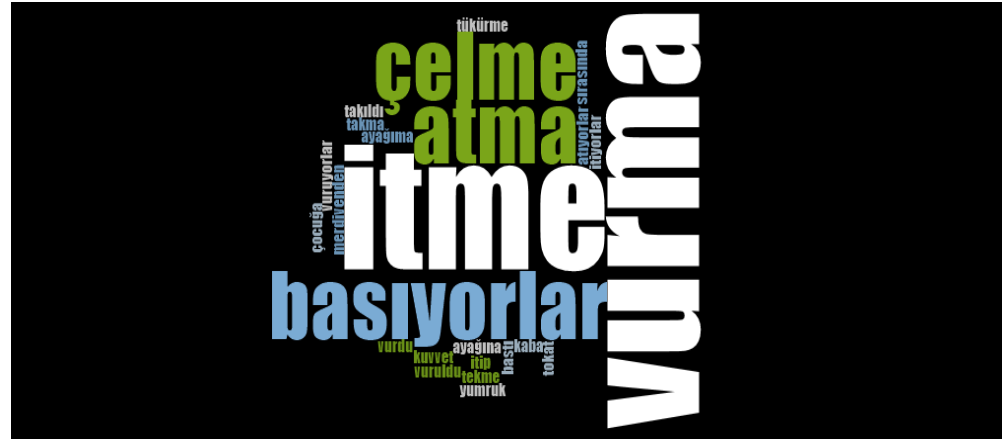

Görsel 4. Öğrenciye uygulanan fiziksel zorbalık çeşitlerine ilişkin öğretmen görüşleri

\section{2. Öğrenciye Uygulanan Akran Zorbalığının Sıklığı ve Süresine İlişkin Öğretmen Görüșleri}

Zihin yetersizliği olan öğrenciye uygulanan akran zorbalığının sıklı̆̆ı ve süresine ilişkin öğretmen görüşlerini içeren bulgulara Tablo 7' de yer verilmiştir.

Tablo 7. Öğrenciye uygulanan akran zorbalığının sıklı̆̆ı ve süresine ilişkin öğretmen görüşleri

\begin{tabular}{lcc}
\hline Akran zorbalığının türü & Sıklığı ve süresi & Frekans \\
\hline Fiziksel zorbalık & Her ders/teneffüs & 2 \\
& Her gün & 2 \\
& Haftada 2-3 kez & 1 \\
Sözel zorbalık & Haftada 2-3 kez & 3 \\
& Haftada 1 kez & 2 \\
& Çok seyrek & 1 \\
Sosyal zorbalık & Her gün & 1 \\
& Haftada 2-3 kez & 1 \\
\hline
\end{tabular}


Akran zorbalığının sıklığını ve süresini belirlemek amacıyla öğretmenlerin verdikleri yanıtlar analiz edilmiş ve öğretmenlerin uygulanan her bir zorbalık türünün sıklığına ilişkin; fiziksel zorbalığının her ders/teneffüs ( $\mathrm{n}=2)$, her gün $(\mathrm{n}=2)$ ve haftada 2-3 kez $(\mathrm{n}=1)$; sözel zorbalığın haftada $2-3 \mathrm{kez}(\mathrm{n}=3)$, haftada $1 \mathrm{kez}(\mathrm{n}=2)$ ve çok seyrek $(\mathrm{n}=1)$ ve sosyal zorbalığın her gün $(\mathrm{n}=1)$ ve haftada 2-3 kez $(n=1)$ uygulandığına dair görüş belirttikleri sonucuna ulaşılmıştır.

Zihin yetersizliği olan öğrenciye uygulanan fiziksel, sözel ve sosyal zorbalık türlerinin sıklığına ilişkin bulgulardan örneklere aşağıda yer verilmiştir.

Fiziksel zorbal1k: "Vurma, itme, merdivenden itme, çelme takma...Şikayetlerine göre her gün oluyor." (Ö6)

Sözel Zorbalık: "Dalga geçme. Deli diyorlar...Eskiden günde 4-5 defaydl. Şimdi haftada 1-2 ye düştü." (Ö21)

Sosyal Zorbalık: “...derste cevap veremediğinde ya da yanlış söylediğinde gülüşüyorlar. $O$ şekilde rencide ediyorlar... Haftada 2-3 kez” (Ö8)

\subsection{Akran Zorbalığının Gözlendiği Ortamlara İlişkin Öğretmen Görüşleri}

Akran zorbalığının gözlendiği ortamlara ilişkin öğretmen görüşlerini içeren bulgular Tablo 8’ de yer almaktadir.

Tablo 8. Öğretmenlerin akran zorbalığının gözlendiği ortamlara ilişkin görüşleri

\begin{tabular}{lc}
\hline Akran zorbalı̆̆nın gözlendiği ortamlar & Frekans \\
\hline Okul bahçesi & 11 \\
Sinıf & 10 \\
Tuvalet & 1 \\
\hline
\end{tabular}

Görüşülen öğretmenlerden 11'i, “İsim takılması okul bahçesinde olmuş.” (Ö2) ifadesinde olduğu gibi akran zorbalığının bahçede gerçekleştiğini, 10’u “...teneffüslerde sinıfin içinde” (Ö29) ifadesindeki sınıfta uygulandığ1 dile getirmiş, öğretmenlerden biri (Ö23) özellikle kız öğrencilerin tuvalette akran zorbalığı uyguladıklarını "Teneffüs ile ögretmenin derse girdiği süreç içerisinde kızlar en çok tuvalette kavga ediyorlar." şeklinde ifade etmiştir.

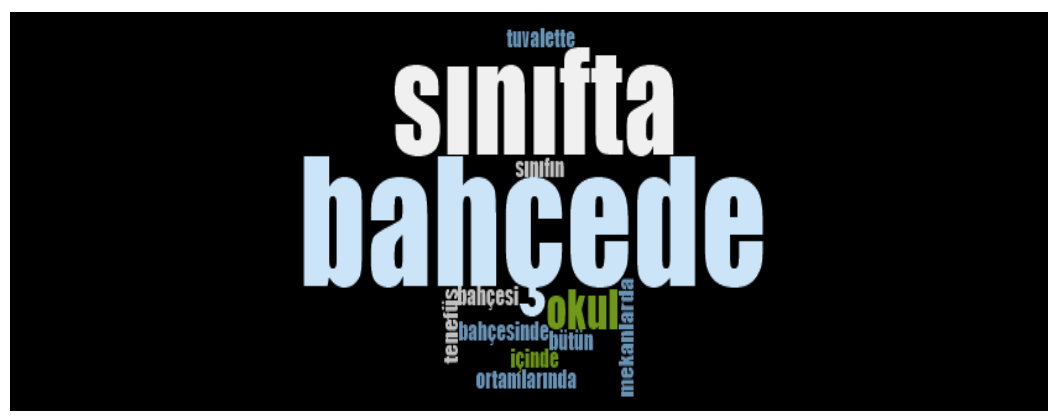

Görsel 5. Öğretmenlerin akran zorbalığının gözlendiği ortamlara ilişkin görüşleri

\subsection{Akran Zorbalığının Gözlendiği Zamanlara İlişkin Öğretmen Görüşleri}

Akran zorbalığının gözlendiği zamanlara ilişkin öğretmen görüşlerini içeren bulgular Tablo 9' da sunulmuştur.

Tablo 9. Öğretmenlerin akran zorbalığının gözlendiği zamanlara ilişkin görüşleri

\begin{tabular}{lc}
\hline Akran zorbalığının gözlendiği zamanlar & Frekans \\
\hline Teneffüs & 13 \\
Ders & 8 \\
\hline
\end{tabular}

"Teneffüslerde oldu bunlar hep derste hiç olmadl." (Ö9) ve "Teneffüslerde, ögrretmen kontrolünün olmadı̆̆ zamanlarda." (Ö29) ifadelerinde olduğu gibi öğretmenlerden 13’ü akran zorbalığının teneffüste uygulandığını; "Ders saatinde de çok oldu, teneffüs teneffüste herkes bahçeye çıtıtı̆ı için çok olmuyor." (Ö10) ve "Derste gözlemledim. Teneffüste bahçede herkes, başka yerlerde orda gözlemlemedim." (Ö8) ifadelerinde görüldüğü gibi öğretmenlerden sekizi zihin yetersizliği olan öğrenciye uygulanan akran zorbalığının ders saatinde meydana geldiğini dile getirmişlerdir. 


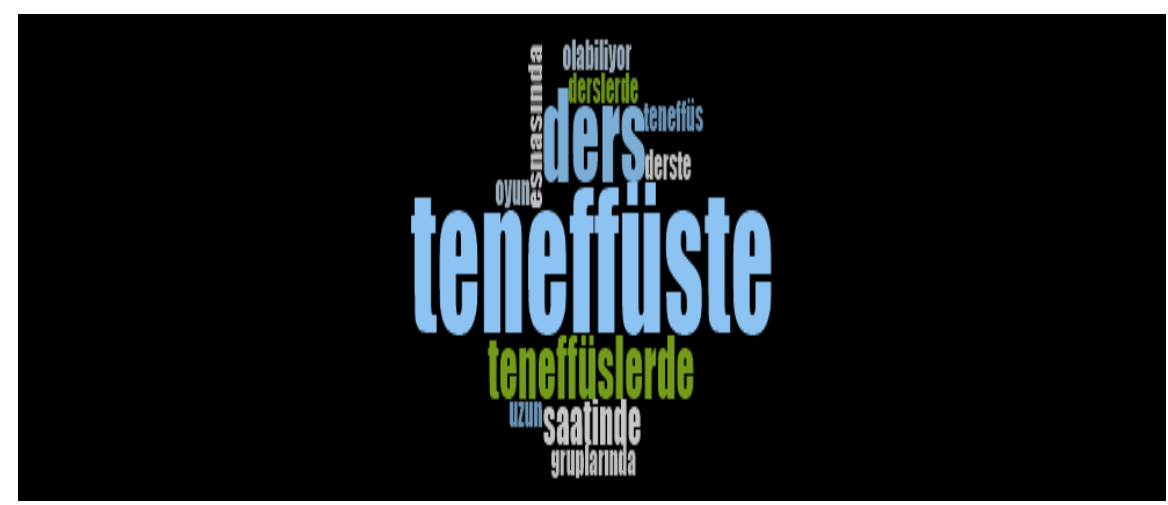

Görsel 6. Öğretmenlerin akran zorbalığının gözlendiği zamanlara ilişkin görüşleri

\subsection{Akran Zorbalığını Uygulayan Kişi İle İlgili Öğretmen Görüşleri}

Akran zorbalığını uygulayan kişi ile ilgili öğretmen görüşlerini içeren bulgulara Tablo 10' da yer verilmiştir.

Tablo 10. Akran zorbalığını uygulayan kişi ile ilgili öğretmen görüşleri

\begin{tabular}{lc}
\hline Akran zorbalığını uygulayan kişi & Frekans \\
\hline Sınıf arkadaşları & 19 \\
Okuldaki diğer çocuklar & 5 \\
\hline
\end{tabular}

Tablo 10'da görüldüğü gibi, zihin yetersizliği olan öğrenciye akran zorbalığg uygulandığını belirten 19 öğretmen zorbalığın öğrencinin sınıf arkadaşları tarafından uygulandığına vurgu yapmış; beş öğretmen ise akran zorbalığının okuldaki diğer (sınıf arkadaşı olmayan) çocuklar tarafından uygulandığını dile getirmişlerdir.

Zihin yetersizliği olan öğrenciye sınıf arkadaşları tarafından zorbalık uygulandığını dile getiren 19 öğretmenden üçü, "Öncelikle sınıf arkadaşları tarafindan yapıldı çünkü çocuk dışarlya çıkmıyordu zaten başkalarını tanımadı̆̆ için onlarla birlikte olmuyordu." (Ö9) ve "Okuldaki diğer çocuklar onu tanımıyor." (Ö25) ifadelerinde olduğu gibi zorbalığın öncelikle sınıf arkadaşları tarafından gerçekleştiğini, bunun sebebinin de öğrencinin sınıf dışına çıkmamasından dolayı diğer çocukların onu tanımaması ve zorbalık uygulayamaması olduğunu belirtmişlerdir.

Yapılan görüşmelerde okuldaki diğer çocukların zorbalık uyguladığını belirten öğretmenlerden (Ö2), akran zorbalığının sınıf arkadaşları tarafından uygulanmamasının sebebini kaynaştırma öğrencisinin sınıf arkadaşları tarafindan benimsenmesine bağlamış ve bunu "Okuldaki çocuklar daha çok yapıyor, sınıfta kaynaștığı için." ifadesiyle dile getirmiştir.

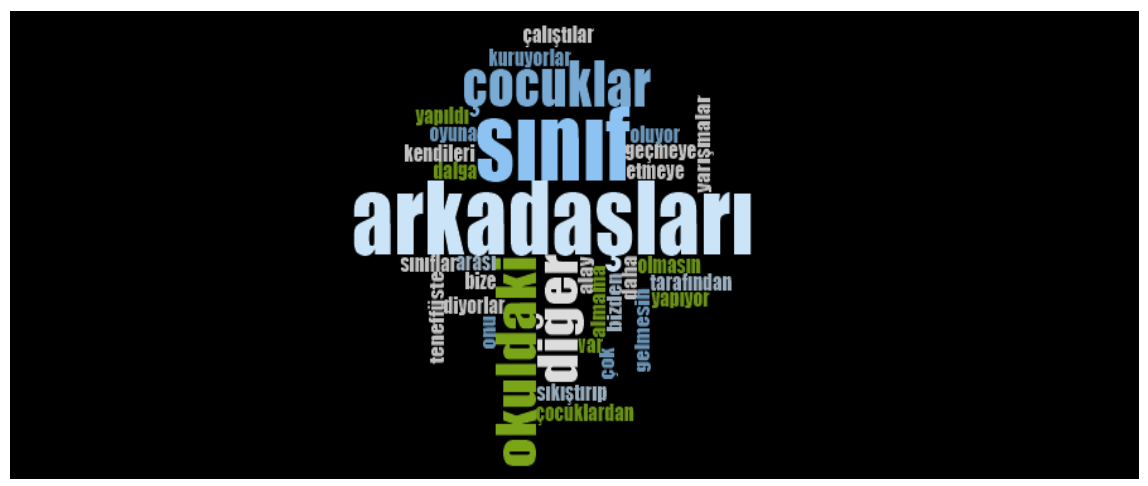

Görsel 7. Akran zorbalığını uygulayan kişi ile ilgili öğretmen görüşleri

\subsection{Akran Zorbalığı Uygulanırken Sınıftaki Diğer Çocukların Tutum ve Davranışlarına İlişkin Öğretmen Görüsşeri}

Zihin yetersizliği olan öğrenciye akran zorbalığı uygulanırken sınıftaki diğer çocukların tutum ve davranışlarına ilişsin öğretmen görüşlerini içeren bulgular Tablo 11' de sunulmuştur. 
Tablo 11. Akran zorbalığı uygulanırken sınıftaki diğer çocukların tutum ve davranışlarına ilişkin öğretmen görüşleri

\begin{tabular}{lc}
\hline Diğer çocukların tutum ve davranışları & Frekans \\
\hline Diğer çocukların onu koruması/savunması & 11 \\
Diğer çocukların tepkisiz kalması & 4 \\
Diğer çocukların da ona zorbalık uygulaması & 4 \\
\hline
\end{tabular}

Sınıfındaki zihin yetersizliği olan öğrenciye akran zorbalığı uygulandığını ifade eden öğretmenlerden 11 'i özel gereksinimli öğrenciye zorbalık uygulanırken sınıftaki diğer çocukların onu koruduğunu/savunduğu, dördü zorbalık sırasında diğer çocukların tepkisiz kaldığını ve dördü de zihin yetersizliği olan öğrenciye zorbalık uygulandığını gören diğer çocukların da zorbalık eylemine katıldığını ifade etmişlerdir.

“Öğrencime akran zorbalığı uygulanırken diğer çocuklar onu koruyorlar/savunuyorlar” şeklinde görüş belirten öğretmenlerin ifadelerinden yapılan doğrudan alıntılar aşağıda sunulmuştur.

"Diğer arkadaşları uyarır sözlü olarak. Öyle söylenir mi, niye öyle söylüyorsun diye." (Ö23)

"Bir bașka sinıftan tepki geldiğinde arkadașlart savunmaya geçerler." (Ö28)

Öğretmenlerden dördü "Diğer çocuklar kendilerine eş bulduğu için mutlu oluyor oyunda, onlar etkilenmiyorlar. Savunma da olmuyor." (Ö25) ifadesinde olduğu gibi zihin yetersizliği olan öğrenciye akran zorbalığı uygulanırken diğer çocukların tepkisiz kaldığını ifade etmişlerdir.

Görüşülen öğretmenlerden dördü sınıfındaki kaynaştırma öğrencisine akran zorbalığ uygulanırken, diğer çocukların da kaynaştırma öğrencisine zorbalık uygulamak için o kişiye/gruba destek verdiğini ve zorbalık uyguladığını belirtmişlerdir. Aşağıda diğer çocukların da zorbalık davranışına katıldıklarını belirten öğretmenlerin ifadelerinden örneklere yer verilmiştir.

"Diğer çocuklar da arkasindan geliyor yani alay etmeye... Fazla bir koruma olmuyor onlar da üstüne siddetlendiriyorlar yani olayl" (Ö16)

"Bazıları aslında farkındayım yapanları destekliyorlar. Aslında gördükleri bildikleri bir şey yok evet evet ögretmenim öyle yaptı diye sonra hayır ben kameralardan izledim hiç öyle bir şey yok deyince dönmeye başllyorlar." (Ö30)

\section{7. Öğrencinin Arkadaşları Tarafından Kendisine Uygulanan Zorbalık İle İlgili Paylaşımlarına İlişkin Öğretmen Görüşleri}

Zihin yetersizliği olan öğrencinin arkadaşları tarafindan kendisine uygulanan zorbalık ile ilgili paylaşımlarına ilişkin öğretmen görüşlerini içeren bulgular Tablo 12' de yer almaktadır.

Tablo 12. Öğrencinin arkadaşları tarafından kendisine uygulanan zorbalık ile ilgili paylaşımlarına ilişkin öğretmen görüşleri

\begin{tabular}{lc}
\hline Öğrencinin akran zorbalığı ile ilgili paylaşımları & Frekans \\
\hline Öğrencinin kendisine zorbalık uygulayan öğrenciyi/öğrencileri şikâyet etmesi & 12 \\
Öğrencinin kendisine zorbalık uygulayan öğrenci/öğrenciler ile ilgili herhangi bir & 4 \\
şey paylaşmaması &
\end{tabular}

Akran zorbalığına maruz kalan zihin yetersizliği olan öğrencinin paylaşımları ile ilgili, öğretmenlerden 12'si öğrencinin kendisine zorbalık uygulayan öğrenciyi/öğrencileri şikâyet ettiğgini dile getirmiş, öğretmenlerden dördü öğrencinin kendisine zorbalık uygulayan öğrenciye/öğrencilere ilişkin kendisi ile herhangi bir şey paylaşmadığını belirtmişlerdir.

Özel gereksinimli öğrencinin kendisine akran zorbalığı uygulayan öğrenciyi/öğrencileri şikâyet ettiğini belirten öğretmenlerin ifadelerinden alıntılar sunulmuştur.

"Şikâyet ediyor. Bana vurdu, bana tükürdü, bana çelme taktı diye. Cezalandırmamı umuyor."

“Alay ediyorlar diyor dalga geçiyorlar așağllyyorlar beni diye söylüyor." (Ö16)

Zihin yetersizliği olan öğrencinin kendisine uygulanan zorbalığa ilişkin öğretmeni ile herhangi bir paylaşımda bulunmadığ " $O$ bana hiçbir șey söylemedi ifade edemedi" (Ö9) ifadesinde olduğu gibi dört öğretmen tarafindan dile getirilmiştir.

\section{8. Öğrenciye Yapılan Zarar Verici Davranışların Kasıtı Olup Olmamasına İlişkin Öğretmen Görüşleri}


Zihin yetersizliği olan öğrenciye yapılan zarar verici davranışların kasıtlı olup olmaması ile ilgili öğretmen görüşlerini içeren bulgular Tablo 13' de sunulmuştur.

Tablo 13. Öğrenciye yapılan zarar verici davranışların kasıtlı olup olmamasına ilişkin öğretmen görüşleri

\begin{tabular}{lc}
\hline Zarar verici davranışların kasıtlı olup olmaması & Frekans \\
\hline Kasıtlı değil & 11 \\
Kasıtlı & 4 \\
\hline
\end{tabular}

Tablo 13'de görüldüğü gibi öğretmenlerin 11'i zarar verici davranışların kasıtlı olmadığını belirtirken; öğretmenlerden dördü bu davranışların kasıtlı bir şekilde zarar verme amacıyla yapıldığını dile getirmişlerdir.

Normal gelişim gösteren öğrenciler tarafindan uygulanan akran zorbalığının kasıtlı olup olmamasına dair, 11 öğretmen öğrencilerin zarar verme davranışlarının kasıtlı olmadığını belirtmişlerdir.

"Kasıtll değill. Arkadaşlık iliş̧kileri çerçevesinde çocuksu davranışlar. Arkadaşça onun nasıl etkileneceğini düşünmeden yapılan davranışlar." (Ö6)

Zihin yetersizliği olan öğrenciye uygulanan zarar verici davranışların kasıtlı olduğunu belirten öğretmenlerden alıntılar aşağıda sunulmuştur.

"Kasıtll yapıyor... Ya öğretmen genelde biraz onla fazla ilgilendiği için kıskanıyorlar. Niye ögretmen onunla ilgileniyor da bizimle ilgilenmiyor diye, ya şimdi ben kaynaştırma ögrencilerine daha fazla ilgi gösteriyorum. Sinıfta ders anlatırken işte yanına gidiyorum geliyorum yardım ediyorum, otomatikman genelde bu kızlarda çok fazla, niye ögretmen onunla ilgileniyor da bizimle ilgilenmiyor diye ona sataşlyorlar." (Ö16)

"Kasıtlı mı, yapan çocuklar tarafindan mı? Tabi bilerek yapıyorlar." (Ö30)

\section{9. Öğrenciye Uygulanan Akran Zorbalığının Öğrenciyi Olumsuz Etkileme Durumuna İlişkin Öğretmen Görüssleri}

Zihin yetersizliği olan öğrenciye uygulanan akran zorbalığının öğrenciyi olumsuz etkileme durumuna ilişkin öğretmen görüşlerini içeren bulgular Tablo 14' de sunulmuştur.

Tablo 14. Öğrenciye uygulanan akran zorbalığının öğrenciyi olumsuz etkileme durumuna ilişkin öğretmen görüşleri

\begin{tabular}{lc}
\hline Akran zorbalığının öğrenciyi olumsuz etkileme durumu & Frekans \\
\hline Öğrencinin olumsuz şekilde etkilenmemesi & 11 \\
Öğrencinin olumsuz şekilde etkilenmesi & 4 \\
\hline
\end{tabular}

Tablo 14'e göre, 11 öğretmen öğrencisinin uygulanan akran zorbalığından olumsuz şekilde etkilenmediğini, öğrencilerin kendilerine uygulanan zorbalığın farkında olmadıklarını veya bir süre sonra bu davranışı unuttuklarını belirtmişlerdir. Zihin yetersizliği olan öğrencinin olumsuz şekilde etkilenmediği görüşünde olan öğretmenlerin ifadelerinden örnekler aşağıda yer almaktadır.

"Hiç öyle bir şeyin farkında bile değil, evet kendine zorbalık yapıldı̆̆ının farkında bile değil, evet yani dışlanıldığının farkında bile değil, o aynı şekilde devam ediyor." (Ö10)

"Etkilenmiyordu sonra unutuyordu öbür teneffüse bir şey kalmıyordu." (Ö9)

Dört öğretmen ise öğrencilerinin akran zorbalığından olumsuz şekilde etkilendiğini, öğrencilerin okula gelmek istemediklerini ve üzülüp ağladıklarını ifade etmişlerdir. Öğretmenlerin ifadelerinden alıntılar sunulmuştur.

"Alay ediyorlar diyor dalga geçiyorlar aşağlliyorlar beni diye söylüyor... Gelmek istememelerinin sebeplerinden birisi de bu zaten okula gelmek istememesinin sebebi... Devamsizlıklarınin sebeplerinden biri de bu." (Ö16)

"Okula gelmeyi seviyor ama bir süre etkilendi. Dördüncü sinıflar onu sikıştırı alay etmeye dalga geçmeye çalıştılar. Onu bir dairenin içine alıp etrafinda bir şeyler yaptıklarını gördüm. Hemen müdahale ettik diğer öğretmen arkadaşlarla. Çocuklarla konuştuk uyardık. Sonrasında o çocuklar gelip ondan özür dilediler. Bu olay olunca bir süre sınıftan dıșarı çıkmak istemedi. " (Ö29)

\section{3. Öğretmenlerin Akran Zorbalığına İlişsin Çözümleri}


Öğretmenlerin akran zorbalığını önlemeye yönelik çözümlerini belirlemek amacıyla görüşleri alınmış ve verdikleri yanıtların analizi sonucunda akran zorbalığına ilişkin çözümleri ile ilgili bulgulara Tablo 15'de yer verilmiştir.

Tablo 15. Öğretmenlerin akran zorbalığına ilişkin çözümleri

\begin{tabular}{lc}
\hline Öğretmenlerin Çözümleri & Frekans \\
\hline Bilgilendirme & 14 \\
Uyarma & 11 \\
Empati kurdurma & 11 \\
Veli ile görüşme & 5 \\
Yetersizliği olan öğrencinin güçlü yanlarını ortaya çıkarma & 4 \\
Diğer öğrencilere örnek/model olma & 4 \\
Cezalandırma & 3 \\
Herhangi bir şey yapmama & 1 \\
\hline
\end{tabular}

Öğretmenlerin akran zorbalığını önlemeye yönelik çözümleri ile ilgili; normal gelişim gösteren öğrencileri yetersizliği olan öğrenci hakkında bilgilendirme $(n=14)$, yetersizliği olan öğrenciye zorbalık uygulayan öğrencileri uyarma $(n=11)$ ve yetersizliği olan öğrenciye zorbalık uygulayan öğrencilere empati kurdurma $(n=11)$ ifadelerini vurguladıkları görülmektedir. Öğretmenlerin beşi yetersizliği olan öğrenciye zorbalık uygulayan öğrencilerin velileri ile görüştüğünü, dördü yetersizliği olan öğrencinin güçlü yanlarını ortaya çıkardığını, dördü yetersizliği olan öğrenciye karşı olumlu şekilde davranarak diğer çocuklara örnek/model olmaya çalıştığını, üçü yetersizliği olan öğrenciye zorbalık uygulayan öğrencileri cezalandırdığını dile getirmişlerdir. Öğretmenlerden sadece biri (Ö7) akran zorbalığını önlemek için "Herhangi bir şey yapmadım" ifadesini kullanmıştır.

Zihin yetersizliği olan öğrenciye uygulanan akran zorbalığına çözüm olarak, normal gelişim gösteren öğrencileri yetersizliği olan öğrenci ile ilgili bilgilendirdiğini ifade eden öğretmenlerin görüşlerinden alıntılara aşağıda yer verilmiştir.

"Onunla ilgili sorular sordular. Çocuklara o gelmeden açıklama yaptım... Geldiğinde onu sınıfa almayıp çocukları o an bilgilendirdim. Onlar kadar normal davranıș gösteremeyeceğini ve görüntüsünün farklı olduğunu söyledim. " (Ö18)

"Ö̈̆rencinin olmadĭ̆ zamanda, ögrencinin durumunu çocukların anlayabileceğ $i$ seviyede anlatarak yardımcı olabileceğimizi söylüyorum... Açıklayıcı bilgi verdiğinizde çocuk bunu kabullenir. Öğretmenin bilgi vermesi önemli. " (Ö28)

Yetersizliği olan öğrenciye zorbalık uygulayan öğrencileri uyardığını dile getiren öğretmen görüşlerinden örnek aşağıda sunulmuştur.

"Dördüncü sınıflar onu sıkıştırıp alay etmeye dalga geçmeye çalıştılar. Onu bir dairenin içine alıp etrafinda bir şeyler yaptıklarını gördüm. Hemen müdahale ettik diğer ögrretmen arkadaşlarla. Çocuklarla konuştuk uyardık." (Ö29)

Yetersizliği olan öğrenciye zorbalık uygulayan öğrencilere empati kurdurduğunu belirten öğretmenlerden alıntılara aşağıda yer verilmiştir.

"Gülüşmelere çok nadir derslerde şahit oldum. Sende yanllş cevap verebilirsin, kendini onun yerine koy şeklinde konuştum." (Ö8)

"Empati kurmalarını sağladım. Her davranışta bunu söyledim, sana yapılsa hoşuna gider mi?"

Yetersizliği olan öğrenciye zorbalık uygulayan öğrencilerin velileri ile görüştüğünü dile getiren öğretmenlerin görüşlerinden örnekler aşă̆ıda yer almaktadır.

"Çok ileri bir safhadaysa veli ile görüssebiliyoruz bunun sebebini” (Ö17)

"Bunu yapan çocukları birebir çağırıyorum ailelerini" (Ö19)

Zihin yetersizliği olan öğrenciye uygulanan akran zorbalığına çözüm olarak, yetersizliği olan öğrencinin güçlü yanlarını ortaya çıkardığını dile getiren öğretmenlerin görüşlerinden alıntı aşağıda sunulmuştur.

“Onun kuvvetli yönlerini ortaya çıkararak önledim." (Ö4)

Yetersizliği olan öğrenciye karşı olumlu tutum sergileyerek diğer öğrencilere örnek/model olduğunu belirten öğretmenlerden doğrudan alıntılar aşağıda yer almaktadır. 
"Önce kendim sayg ve sevgi gösterdim, örnek oldum. Onun değerli bir birey olduğunu hissettirdim." (Ö4)

"Akran zorbalı̆̆ının olmaması sebebi benim tutumum bence biraz. Ben çalışmalar sırasında onu hiç sınıfin dışında bırakmadım. Tüm çalışmalara onu da kattım. Özellikle 1. sınıfta hep yanında durdum. Arkadaşları da beni örnek alarak onunla ilgilendiler." (Ö1)

Zihin yetersizliği olan öğrenciye zorbalık uygulayan öğrencileri cezalandırdığını dile getiren öğretmenlerin ifadelerinden örnekler aşağıda sunulmuştur.

"Bireysel konuşmalar işe yaramazsa sert cezalar verdiğim de oldu." (Ö9)

"Derste onu fazla derse kaldırmama, ondan sonra ödevlerde onla gidip ilgilenmeme böyle cezalar veriyorum. " (Ö16)

\section{TARTIŞMA VE SONUÇ}

Kaynaştırma sınıfına devam eden zihin yetersizliği olan öğrencilere uygulanan akran zorbalığına ilişkin öğretmen görüşlerinin belirlenmesi amacıyla yürütülen araştırmadan elde edilen bulgular ulaşılabilen alanyazın ile karşılaştırılarak tartışılmış ve sonuçlar doğrultusunda öneriler getirilmiştir.

Katılımcıların görüşleri incelendiğinde öğretmenlerin akran zorbalığı ile ilgili çağrışımlarının; şiddet uygulamak, itmek, vurmak, aşağılamak, baskı yapmak, zorla bir şey yaptırmak ve alay etmek kavramlarından oluştuğu görülmektedir. Öğretmenler akran zorbalığını en sık "şiddet uygulamak" kavramı ile bağdaştırmışlardır. Bunun yanı sıra öğretmenlerin akran zorbalığını fiziksel zorbalık ile daha çok bağdaştırdıkları (itmek ve vurmak), sözel zorbalık çeşitlerinden sadece alay etmeyi dile getirdikleri ve diğer sözel zorbalık türlerine yer vermedikleri görülmektedir. Yapılan araştırmalarda akran zorbalığ̣ türlerinden en çok sözel zorbalığın gerçekleştiği (Bear, Mantz, Glutting, Yang ve Boyer, 2015; Norwich ve Kelly, 2004; Zeedyk, Rodriguez, Tipton, Baker ve Blacher, 2014); fakat akran zorbalığının öğretmenlerde fiziksel hasar bırakan ve gözlenebilen davranışları çağrıştırdığı görülmektedir. Alan yazında özel gereksinimli bireylere uygulanan sosyal zorbalık çeşitlerinden biri; yetersizliği olan çocuğun dışlanması (Llewellyn, 2000) olmasına rağmen, öğretmenlerin akran zorbalığına ilişkin çağrışımlarında "dışlanma" ifadesini kullanmadıkları görülmüştür.

Öğretmenlerin 15'i akran zorbalığının sebebi olarak, zorbalık uygulayan çocuğun ailevi özelliklerini göstermiştir. Ailesinde zorbalık olan çocukların okulda akranlarına zorbalık uygulama olasılıkları olduğunu, çocuğun ailesinde şahit olduğu veya bizzat yaşadığı (dövme gibi) olayları/sıkıntıları okula yansıttı̆̆ını dile getiren öğretmenlerin ifadeleri Banks (1997), Bowes ve diğerleri (2009) ve Aküzüm ve Oral'ın (2015) ifadeleri ile benzerdir. Banks (1997) ilginin ve sicaklığın az olduğu, problemleri çözmek için fiziksel şiddete başvurulan ve fiziksel cezaların verildiği bir aile ortamına sahip çocukların zorbalık sergilediğini belirtmiştir. Bowes ve diğerleri (2009) ile Aküzüm ve Oral (2015) da aileden şiddet görmenin ve aile içi şiddete tanık olmanın zorbalıkla ilişkisi olduğunu ifade etmişlerdir.

Öğretmenlerden dördü akran zorbalığının sebebi olarak özel gereksinimli öğrencinin gelişimsel geriliğinin olmasını ifade etmiştir. Araştırmanın sonuçları, kaynaştırma uygulaması kapsamında genel eğitim sınıflarına devam eden yetersizliği olan öğrencilerin sosyal becerileri yetersizliklerinin olmasının (Blake ve diğ., 2012; Christensen, Fraynt, Neece ve Baker, 2012; Rose ve Monda-Amaya, 2011; Son, 2011; Son ve diğ, 2014), zihinsel ve bilişsel olarak yaşıtları ile aynı seviyede olmamalarının (geri olmaları) (Carter ve Spencer, 2006) ve problem davranışlar sergilemelerinin (Rose, Espelage ve Monda-Amaya, 2009; Rose, Monda-Amaya ve Espelege, 2011) özel gereksinimli çocukların akranları tarafından zorbalığa maruz kalmasında olası sebepler arasında olabileceğini ifade eden alanyazındaki çalışmalarla paralellik göstermektedir.

Öğretmenlerin ifadeleri doğrultusunda zihin yetersizliği olan öğrenciye en sık uygulanan zorbalık türleri sırasıyla sözel zorbalık, sosyal zorbalık ve fiziksel zorbalık olarak bulunmuş olup, bu bulgu Bear ve diğ. (2015) ile Hartley, Bauman, Nixon ve Davis'in (2015) çalışmaları ile paralellikle göstermektedir. Araştırmada ortaya çıkan bu sonucun aksine; Andreou, Didaskalou ve Vlachou (2015) ile Dickinson (2006) çalışmalarında özel gereksinimli bireylere uygulanan zorbalık türlerini araştırmışlar ve en sık gözlenen zorbalık türünün fiziksel zorbalık olduğunu belirtmişler; Kabasakal, Girli, Okun, Çelik ve Vardarlı (2008) kaynaştırma öğrencilerine uygulanan akran zorbalı̆̆ ile ilgili yürüttükleri çalışmada, özel gereksinimli çocukların normal gelişim gösteren akranları tarafından 
fiziksel zorbalığa maruz kalma oranının \%68.8, sözel zorbalığa maruz kalma oranının ise \%25 olduğu sonucuna ulaşmışlardır. Son (2011) ise yürüttüğü araştırmada, gözlemlenen zorbalık türlerini en çok gözlemlenenden en az gözlemlenene doğru sosyal zorbalık, sözel zorbalık ve fiziksel zorbalık olarak siralamıştır.

Sözel zorbalık türleri ile ilgili bulgular incelendiğinde öğretmenlerin en çok dalga geçme/alay etmeyi, ardından sözel olarak sataşma ve isim takmayı gözlemledikleri sonucuna ulaşılmıştır. Pivik ve diğerleri (2002) kaynaştırma öğrencileri ile yaptıkları görüşmeler sonucunda öğrencilerin en çok rahatsız oldukları sözel zorbalık türlerinin isim takılması, işaret edilerek gösterilme, şaşkın bir ifadeyle kendisine bakılması, alay edilmesi, aptal şeklinde etiketlenmek ve diğer öğrenciler tarafından tehdit edilmek olduğunu belirtmişlerdir. Langevin, Bortnick, Hammer ve Wiebe (1998) ile Norwich ve Kelly (2004) yaptıkları çalışmalarda özel gereksinimli öğrencilerin sözel zorbalık türlerinden en çok isim takmaya maruz kaldığını ifade etmiş̧lerdir.

Kaynaştırma öğrencisine uygulanan sosyal zorbalık türlerine bakıldığında en çok oyuna almama veya almak istememe ve dışlamanın olduğu görülmektedir. Öğretmenlerden bazıları zihin yetersizliği olan öğrencinin oyunlara alınmak istenmediği halde alındığını, bazı öğretmenler ise oyuna hiç alınmadığını dile getirmiş ve bu öğretmenlerin görüşleri oyuna almama/almak istememe alt temasında ele alınmıştır. Dışlama olarak alınan alt tema öğrencinin sosyal izolasyonu ve herhangi bir sosyal gruba alınmaması olarak değerlendirilmiştir. Araştırma sonuçlarına paralel olarak, Çulhaoğlu- İmrak (2009) çalışmasında yetersizliği olan çocukların, normal gelişim gösteren akranları tarafından yeterli bulunmadıkları oyunlara alınmadığını; Andreou ve diğerleri (2015), Pivik ve diğerleri (2002); Swearer, Wang, Maag, Siebecker ve Frerichs (2012) ve Şahbaz (2004) sosyal olarak izole edildiğini ve dışlandığını; Kabasakal ve diğerleri (2008) kaynaştırma öğrencilerinin çok arkadaşlarının olmadığını ve sevilmediklerini, bir eş seçilmesi istendiğinde bir-iki çocuk dışında kimsenin ilk tercihinde kaynaştırma öğrencisini seçmediğini belirtmişlerdir.

Sınıf öğretmenleri zihin yetersizliği olan öğrencilerine akranları tarafindan uygulanan fiziksel zorbalık hakkında en çok vurma ve itme davranışını gözlediklerini ifade etmişlerdir. Langevin ve diğerleri (1998) özel gereksinimli çocuklarla yürüttükleri çalışmada benzer bulgulara ulaşmış ve çocukların akranları tarafından sıklıkla itme davranışına maruz kaldığını belirtmişlerdir.

Akran zorbalığının en çok gözlendiği ortamla ilgili olarak sınıf öğretmenleri, zorbalığın sırasıyla okul bahçesinde, sınıfta ve tuvalette gözlendiğini belirtmiştir. Bu sonuca paralel olarak Andreou ve diğerleri (2015) ile Langevin ve diğerleri (1998) çalışmalarında zorbalığın en çok gözlendiği yerleri oyun alanı (bahçe), sınıf ve koridor olarak ifade etmişlerdir. Dickinson (2006) yetersizliği olan çocukların en çok oyun alanında (bahçe) zorbalığa maruz kaldığını belirtmiştir. Çınkır ve Kepenekci, (2003) de akran zorbalığının gerçekleştiği ortamları sırasıyla; okul bahçesi, sınıf, koridor, okul dışı ve tuvalet olarak sıralamıştır.

Zihin yetersizliği olan öğrenciye akran zorbalığı uygulandığında diğer çocukların tutum ve davranışlarına ilişkin öğretmenlerden 11'i akran zorbalığı uygulandığını gören çocukların özel gereksinimli öğrenciyi koruduğunu dile getirmiştir. Bourke ve Burgman (2010) da benzer şekilde; yetersizliği olan çocuğun zorbalıktan korunmasında arkadaşların (diğer çocukların) önemli bir rol oynadığını ve diğer çocukların zorbalık uygulayanlara karşı özel gereksinimli çocuğu koruduğunu belirtmişlerdir.

Öğrencinin arkadaşları tarafından kendisine uygulanan zorbalık ile ilgili paylaşımlarına ilişkin öğretmen görüşleri incelendiğinde, öğretmenlerden 12'si kaynaştırma öğrencisinin zorbalık uygulayan öğrencileri öğretmenine şikâyet ettiğini belirtmiştir. Benzer şekilde, Andreou ve diğerlerinin (2015) çalışmasında öğrencilerin \%19'unun kendisine uygulanan zorbalığı öğretmeni ile paylaştığ görülmektedir. Öğretmenlerden dördü ise öğrencisinin kendisine uygulanan zorbalık ile ilgili herhangi bir paylaşımda bulunmadığını dile getirmiştir. Bu bulguya paralel olarak, Norwich ve Kelly (2004) çalışmalarında özel gereksinimli çocukların bir kısmının bu durumu görmezden geldiğini, sessiz kaldığını ve durumu öğretmenine söylemediğini ifade etmişlerdir. Green'in (2014) yürüttüğü nitel çalışmada, görüşme yapılan yedi öğrenciden beşinin bunu kimseye bildirmediği, bunun sebebi olarak da öğrencilerden birinin arkadaşları tarafından "tuhaf" şeklinde etiketlenmek istemediğini söylediği görülmüştür. Bourke ve Burgman (2010) ise öğrencilerin zorbalı̆̆g öğretmenlerinden ziyade kendi yaşıtlarıyla paylaştığını ifade etmişlerdir. 
Sınıf öğretmenleri kaynaştırma öğrencisinin akran zorbalığından olumsuz şekilde etkilenmediğini ifade etmiştir. Bu sonuca paralel olarak, Christensen ve diğerleri (2012) kaynaştırma öğrencileri üzerinde zorbalığın ciddi bir etkisinin olmadığını ve zorbalığın onlar üzerindeki olumsuz etkisinin bilişsel özelliklerindeki gecikmelerden dolayı azalmış olabileceğini belirtmişlerdir. Kaynaştırma öğrencisinin akran zorbalığından olumsuz etkilendiğini dile getiren öğretmenlerin Norwich ve Kelly'nin (2004) çalışmasında olduğu gibi kaynaştırma öğrencisinin devamsızlığında artış olduğunu ve okula gelmek istemediğini ifade ettiği görülmektedir. Benzer şekilde Green (2014) de öğrencilerin zorbalık yapılan ortamda bulunmaktan kaçındığını dile getirmiştir.

Kaynaştırma uygulamasında özel gereksinimli öğrencilerin zorbalığa maruz kalmasını önlemek ve akranları tarafindan kabulünü sağlamak amacıyla normal gelişim gösteren öğrenciler kaynaştırma öğrencisi hakkında bilgilendirilmelidir (Batu, 2000; Uysal, 1995). Araştırmadaki öğretmenlerin 14'ü sınıfindaki öğrencileri zihin yetersizliği olan öğrencinin özellikleri (daha yavaş öğrendiği, bazı davranış problemleri olabileceği gibi) hakkında bilgilendirdiklerini ifade etmişlerdir. Bourke ve Burgman'ın (2010) yetersizliği olan ve zorbalığa maruz kalan öğrencilerle yaptıkları çalışmada, öğrencilerden biri akran zorbalığını önlemek için zorbalık uygulayan çocuğun uyarılması veya disiplin cezası ile

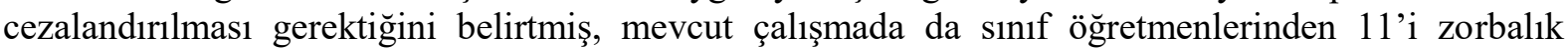
uygulayan öğrenciyi uyardıklarını ifade etmiştir. Görüşme yapılan öğretmenlerden dördü zihin yetersizliği olan öğrenciye karşı olumlu bir tutum sergilediklerini, onu hiçbir etkinliğin dışında bırakmayarak öğrencilere örnek olduklarını dile getirmişlerdir. Batu ve Kırcaali- İftar (2016)'a göre, sınıf öğretmeninin özel gereksinimli öğrenciyi kabul eder bir tutum içerisinde olması, sınıftaki normal gelişim gösteren öğrencilerin de o öğrenciye karşı tutumlarını olumlu yönde etkilemektedir.

Görüşülen öğretmenlerden dördü özel gereksinimli çocukların gelişimsel yetersizliklerinin olduğunu ve bu yüzden de akran zorbalığına maruz kaldıklarını belirtmiştir. Rose ve Monda- Amaya (2011) da benzer şekilde sosyal beceri yetersizliklerinin akran zorbalığına sebep olabileceğini ve sınıf öğretmenlerinin yetersizliği olan çocuklara uygun sosyal becerileri kazandırması ile akranları tarafindan zorbalığa maruz kalmalarının azaltılabileceğini ifade etmişlerdir. Fakat araştırma kapsamında görüşülen öğretmenlerin zorbalığı önlemek için kullandıkları çözüm yollarının uyarma, cezalandırma, zorba öğrencinin ebeveyni ile görüşme gibi sadece zorbalık yapan öğrenciye yönelik olduğu, yetersizliği olan öğrenci ile herhangi bir çalışma yapılmadığı görülmektedir.

Araştırma sonucunda, sınıf öğretmenlerinin akran zorbalığının tanımı ve sebeplerine ilişkin algılarının, gözlemlenen zorbalık türlerinin, zorbalığın gözlendiği ortam ve zamanların ve zorbalığa ilişkin çözümlerin alanyazınla tutarlı olduğu görülmektedir. Öğretmenler zihin yetersizliği olan öğrenciye akranları tarafindan sözel, sosyal ve fiziksel zorbalık uygulandığını gözlemlediklerini, buna çözüm olarak çeşitli çalışmalar yaptıklarını dile getirmişlerdir. Öğretmenlerin önleme çalışmaları ve zorbalığın görülme sılığı birlikte düşünüldüğünde öğretmenlerin çözümlerinin zorbalığı önlemek için yeterli olmadığı düşünülmektedir. Öğretmenlerin büyük kısmı ailevi özellikleri zorbalığın sebebi olarak göstermiştir. Buna karşın öğretmenlerin zorbalığı önlemede kullandıkları çözümlerde veli ile görüşme az kullanılan çözümlerden biri olarak karşımıza çıkmıştır. Öğretmenlerin zihin yetersizliği olan öğrencinin zorbalıktan etkilenmediğini düşünmeleri de akran zorbalığına yeterli düzeyde müdahale edilmemesinin bir sebebi olarak görülebilir. Bu sonuçlara dayalı olarak sınıf öğretmenlerinin zorbalık konusunda hizmet öncesi ve hizmet içi eğitimlerle bilgilendirilmesi ve bu konuda okul çaplı izleme ve önleyici yaklaşımların uygulanması önerilebilir. Araştırma bulguları, zihin yetersizliği olan öğrencilere yönelik akran zorbalığının önlenmesinde ailelere, sınıf öğretmenlerine, normal gelişim gösteren ve özel gereksinimli çocuklara yönelik çalışmalara gereksinim olduğunu göstermektedir.

\section{KAYNAKÇA}

AAIDD. (2010). FAQs on Intellectual Disability. 13.04.2016 tarihinde https://aaidd.org/intellectualdisability/definition/faqs-on-intellectual disability\#.Vw5O9NSLQ1g adresinden erişildi.

Aküzüm, C., \& Oral, B. (2015). Yönetici ve öğretmen görüşleri açısından okullarda görülen en yaygın şiddet olayları, nedenleri ve çözüm önerileri. EKEV Akademi Dergisi, 61, 1-30.

Andreou, E., Didaskalou, E., \& Vlachou, A. (2015). Bully/victim problems among Greek pupils with special educational needs: Associations with loneliness and self-efficacy for peer interactions. Journal of Research in Special Educational Needs, 15(4), 235-246. 
Banks, R. (1997). Bullying in Schools. ERIC Digest. Retrieved from: http://files.eric.ed.gov/fulltext/ED407154.pdf

Batu, E. S. (2000). Özel gereksinimli öğrencilerin kaynaştırıldı ̆̆ bir kız meslek lisesindeki öğretmenlerin kaynaştırmaya ilişkin görüş ve önerileri. Eskişehir: Anadolu Üniversitesi Yayınları, No: 1242.

Batu, E. S., \& Kırcaali-İftar, G. (2016). Kaynaştırma. Ankara: Kök Yayıncılık.

Bear, G. G., Mantz, L. S., Glutting, J. J., Yang, C., \& Boyer, D. E. (2015). Differences in bullying victimization between students with and without disabilities. School Psychology Review, 44(1), 98-116.

Blake, J. J., Lund, E. M., Zhou, Q., Kwok, O. M., \& Benz, M. R. (2012). National prevalence rates of bully victimization among students with disabilities in the United States. School Psychology Quarterly, 27(4), 210-222.

Bourke, S., \& Burgman, I. (2010). Coping with bullying in Australian schools: How children with disabilities experience support from friends, parents and teachers. Disability \& Society, 25(3), 359-371.

Bowes, L., Arseneault, L., Maughan, B., Taylor, A., Caspi, A., \& Moffitt, T. E. (2009). School, neighborhood, and family factors are associated with children's bullying involvement: A nationally representative longitudinal study. Journal of the American Academy of Child ve Adolescent Psychiatry, 48(5), 545-553.

Britten, N. (1995). Qualitative research: Qualitative interviews in medical research. Bmj, 311, 251-253.

Carter, B. B., \& Spencer, V. G. (2006). The fear factor: Bullying and students with disabilities. International Journal of Special Education, 21(1), 11-23.

Christensen, L. L., Fraynt, R. J., Neece, C. L., \& Baker, B. L. (2012). Bullying adolescents with intellectual disability. Journal of Mental Health Research in Intellectual Disabilities, 5(1), 49-65.

Coloroso, B. (2002). The bully, the bullied and the bystander. New York: HarperCollins.

Çınkır, Ş., \& Kepenekçi, Y. K., (2003). Öğrenciler arası zorbalık. Kuram ve Uygulamada Eğitim Yönetimi, 34(34), 236-253.

Çulhaoğlu- İmrak, H. (2009). Okulöncesi dönemde kaynaştırma ĕgitimine ilişkin öğretmen ve ebeveyn tutumlart ile kaynaştırma ĕgitimi uygulanan sınıflarda akran ilişkilerinin incelenmesi. Yayınlanmamış yüksek lisans tezi, Çukurova Üniversitesi, Adana, Türkiye.

Dickinson, K. L. (2006). Children with and without disabilities: Perceptions and responses towards bullying at school. Unpublished doctoral dissertation, University of Delaware, USA.

Green, B. (2014). Bullying of individuals with disabilities on a college campus: A Qualitative study. (Unpublished doctoral dissertation, The George Washington University, USA). Retrieved from: https://search.proquest.com/docview/1497970006/92831FE686484197PQ/1?accountid=17170.

Hartley, M. T., Bauman, S., Nixon, C. L., \& Davis, S. (2015). Comparative study of bullying victimization among students in general and special education. Exceptional Children, 81(2), 176-193.

Kabasakal, H. Z., Girli, A., Okun, B., Çelik, N., \& Vardarlı, G. (2008). Kaynaştırma öğrencileri, akran ilişkileri ve akran istismarı. Dokuz Eylül Üniversitesi Buca Ĕ̆itim Fakültesi Dergisi, 23, 169-176.

Kartal, H., \& Bilgin, A. (2012). İlköğretim öğrencilerinin zorbalığın nedenleri ile ilgili algıları. Gaziantep Üniversitesi Sosyal Bilimler Dergisi, 11(1), 25-48.

Langevin, M., Bortnick, K., Hammer, T., \& Wiebe, E. (1998). Teasing/bullying experienced by children who stutter: Toward development of a questionnaire. Contemporary Issues in Communication Science and Disorders, 25, 12-24.

Llewellyn, A. (2000). Perceptions of mainstreaming: A systems approach. Developmental Medicine and Child Neurology, 42(2), 106-115.

Norwich, B., \& Kelly, N. (2004). Pupils' views on inclusion: Moderate learning difficulties and bullying in mainstream and special schools. British Educational Research Journal, 30(1), 43-65.

Olweus, D. (1991). Bully/victim problems among schoolchildren: Basic facts and effects of a school based intervention program. In D.J. Pepler and K.H. Rubin (Eds.), The Development and treatment of childhood aggression (s. 411-448). Lawrence Erlbaum Associates.

Olweus, D. (1993). Bullying at school: What we know and what we can do. Maiden: Blackwell Publishing.

Olweus, D. (1995). Bullying or peer abuse at school: Facts and intervention. Current Directions in Psychological Science, 4(6), 196-200.

Pivik, J., McComas, J., \& Laflamme, M. (2002). Barriers and facilitators to inclusive education. Exceptional Children, 69(1), 97-107.

Rose, C. A., \& Monda-Amaya, L. E. (2011). Bullying and victimization among students with disabilities: Effective strategies for classroom teachers. Intervention in School and Clinic, 48(2), 99-107.

Rose, C. A., Espelage, D. L., \& Monda-Amaya, L. E. (2009). Bullying and victimization rates among students in general and special education: A comparative analysis. Educational Psychology, 29(7), 761-776.

Rose, C. A., Monda-Amaya, L. E., \& Espelage, D. L. (2011). Bullying perpetration and victimization in special education: A review of the literature. Remedial and Special Education, 32(2), 114-130. 
Son, E. (2011). Peer victimization of children with disabilities: Examining prevalence and early risk and protective factors among a national sample of children receiving special education services. Unpublished doctoral dissertation, The State University of New Jersey, USA.

Son, E., Peterson, N. A., Pottick, K. J., Zippay, A., Parish, S. L., \& Lohrmann, S. (2014). Peer victimization among young children with disabilities: Early risk and protective factors. Exceptional Children, 80(3), 368-384.

Swearer, S. M., Wang, C., Maag, J. W., Siebecker, A. B., \& Frerichs, L. J. (2012). Understanding the bullying dynamic among students in special and general education. Journal of School Psychology, 50(4), 503520.

Şahbaz, Ü. (2004). Kaynaştırma sınıflarına devam eden zihin engelli öğrencilerin sosyal kabul düzeylerinin belirlenmesi. A. Konrot (Ed.). 13. Ulusal özel ĕgitim bildirileri: özel ĕgitimden yansımalar içinde (s. 8292). Ankara: Kök Yayıncılik.

Turhan, C. (2007). Kaynaştırma uygulaması yapılan ilköğretim okuluna devam eden normal gelişim gösteren öğrencilerin kaynaştırma uygulamasına ilişkin görüşleri. Yayınlanmamış yüksek lisans tezi, Anadolu Üniversitesi, Eskişehir, Türkiye.

Uysal, A. (1995). Öğretmen ve okul yöneticilerinin zihin engelli çocukların kaynaştırılmasında karşılaşılan sorunlara ilişkin görüşleri. Yayınlanmamış yüksek lisans tezi, Anadolu Üniversitesi, Eskişehir, Türkiye.

Yıldırım, A., \& Şimşek, H. (2013). Sosyal bilimlerde nitel araştırma yöntemleri. (9th. ed.). Ankara: Seçkin Yayıncilik.

Zeedyk, S. M., Rodriguez, G., Tipton, L. A., Baker, B. L., \& Blacher, J. (2014). Bullying of youth with autism spectrum disorder, intellectual disability or typical development: Victim and parent perspectives. Research in Autism Spectrum Disorders, 8(9), 1173-1183. 